\title{
Very short-lived bromomethanes measured by the CARIBIC observatory over the North Atlantic, Africa and Southeast Asia during 2009-2013
}

\author{
A. Wisher ${ }^{1}$, D. E. Oram ${ }^{2}$, J. C. Laube ${ }^{1}$, G. P. Mills ${ }^{1}$, P. van Velthoven ${ }^{3}$, A. Zahn ${ }^{4}$, and C. A. M. Brenninkmeijer ${ }^{5}$ \\ ${ }^{1}$ Centre for Ocean and Atmospheric Sciences (COAS), School of Environmental Sciences, University of East Anglia, \\ Norwich, NR4 7TJ, UK \\ ${ }^{2}$ National Center for Atmospheric Science (NCAS), Centre for Ocean and Atmospheric Sciences (COAS), School of \\ Environmental Sciences, University of East Anglia, Norwich, NR4 7TJ, UK \\ ${ }^{3}$ Royal Netherlands Meteorological Institute (KNMI), P.O. Box 201, 3730 AE, de Bilt, the Netherlands \\ ${ }^{4}$ Karlsruhe Institute of Technology-Atmospheric Trace Gases and Remote Sensing (IMK-ASF), Postfach 36 40, \\ 76021, Karlsruhe, Germany \\ ${ }^{5}$ Max Planck Institute for Chemistry, Air Chemistry Division, Hahn-Meitner Weg 1, 55128, Mainz, Germany \\ Correspondence to: A. Wisher (a.wisher@uea.ac.uk)
}

Received: 22 October 2013 - Published in Atmos. Chem. Phys. Discuss.: 15 November 2013

Revised: 20 February 2014 - Accepted: 21 February 2014 - Published: 8 April 2014

\begin{abstract}
Short-lived organic brominated compounds make up a significant part of the organic bromine budget in the atmosphere. Emissions of these compounds are highly variable and there are limited measurements, particularly in the extra-tropical upper troposphere/lower stratosphere and tropical troposphere. Measurements of five very short-lived bromomethanes (VSLB) were made in air samples collected on the CARIBIC project aircraft over three flight routes; Germany to Venezuela/Columbia during 2009-2011, Germany to South Africa during 2010 and 2011 and Germany to Thailand/Kuala Lumpur, Malaysia during 2012 and 2013.

In the tropical troposphere, as the most important entrance region to the stratosphere, we observe a total mean organic bromine derived from these compounds across all flights at $10-12 \mathrm{~km}$ altitude of $3.4 \pm 1.5 \mathrm{ppt}$. Individual mean tropical tropospheric mixing ratios across all flights were $0.43,0.74,0.14,0.23$ and $0.11 \mathrm{ppt}$ for $\mathrm{CHBr}_{3}, \mathrm{CH}_{2} \mathrm{Br}_{2}$, $\mathrm{CHBr}_{2} \mathrm{Cl}, \mathrm{CHBrCl}_{2}$ and $\mathrm{CH}_{2} \mathrm{BrCl}$ respectively. The highest levels of VSLB-derived bromine $(4.20 \pm 0.56 \mathrm{ppt})$ were observed in flights between Bangkok and Kuala Lumpur indicating that the South China Sea is an important source region for these compounds. Across all routes, $\mathrm{CHBr}_{3}$ and $\mathrm{CH}_{2} \mathrm{Br}_{2}$ accounted for $34 \%(4.7-71)$ and $48 \%$ (14-73) respectively
\end{abstract}

of total bromine derived from the analysed VSLB in the tropical mid-upper troposphere totalling $82 \%$ (54-89).

In samples collected between Germany and Venezuela/Columbia, we find decreasing mean mixing ratios with increasing potential temperature in the extratropics. Tropical mean mixing ratios are higher than extra-tropical values between $340-350 \mathrm{~K}$ indicating that rapid uplift is important in determining mixing ratios in the lower tropical tropopause layer in the West Atlantic tropics.

$\mathrm{O}_{3}$ was used as a tracer for stratospherically influenced air and we detect rapidly decreasing mixing ratios for all VSLB above $\sim 100 \mathrm{ppb} \mathrm{O}_{3}$ corresponding to the extratropical tropopause layer.

\section{Introduction}

Chlorinated and brominated organic compounds have the potential to catalytically destroy ozone in the stratosphere via processes involving the inorganic products of photochemical decomposition. The influence of longlived anthropogenic species such as chlorofluorocarbons (CFCs), bromochlorofluorocarbons and bromofluorocarbons (halons) is well documented. However, short-lived 
compounds with lifetimes of less than $\sim 6$ months, termed very short-lived substances (VSLS), can also transport significant quantities of reactive halogens to the stratosphere. The most significant biogenic brominated VSLS are bromoform $\left(\mathrm{CHBr}_{3}\right)$, dibromomethane $\left(\mathrm{CH}_{2} \mathrm{Br}_{2}\right)$, dibromochloromethane $\left(\mathrm{CHBr}_{2} \mathrm{Cl}\right)$, bromodichloromethane $\left(\mathrm{CHBrCl}_{2}\right)$ and bromochloromethane $\left(\mathrm{CH}_{2} \mathrm{BrCl}\right)$. These very short-lived brominated compounds (VSLB) are emitted predominantly from natural sources namely macroalgae in coastal regions and oceanic phytoplankton (e.g. Leedham et al., 2013; Brinckmann et al., 2012; Carpenter et al., 2009; Montzka and Reimann, 2011). There are also minor contributions of trihalomethanes from drinking water chlorination and power plant cooling water (Quack and Wallace, 2003).

Recent WMO reports (Law and Sturges, 2007; Montzka and Reimann, 2011) indicate that natural halocarbon emissions are associated with significant stratospheric $\mathrm{O}_{3}$ depletion. Bromine has an $\sim 60$ times higher efficiency, on average and on a per atom basis, to destroy ozone than chlorine (Sinnhuber et al., 2009). This, combined with the highly variable spatial and temporal distribution of VSLS in the troposphere, indicates that even at low mixing ratios, brominated VSLS species could contribute significantly to stratospheric ozone depletion. Hossaini et al. (2012a) suggest that VSLS source gas injection into the stratosphere is likely to increase in response to future climate change. Furthermore, as levels of anthropogenic halogenated source gases are predicted to decrease (e.g. Montzka and Reimann, 2011), as a result of the Montreal Protocol, biogenic halocarbons including bromomethanes will become proportionally more significant in the future. Additionally, there is a relative paucity of measurements in the region of the upper troposphere/lower stratosphere (UTLS); an important region when considering the transport of compounds into the stratosphere.

Currently, the best estimate of the contribution of brominated VSLS to inorganic bromine in the stratosphere, as inferred from measurements of inorganic decomposition products such as $\mathrm{BrO}$, is 6 (range 3-8) ppt (Montzka and Reimann, 2011) which represents $\sim 27 \%(13-36)$ of total stratospheric bromine. Uncertainties in this estimate include the high degree of variability in source emissions, limited understanding of transport pathways to the upper tropical tropopause, differences in calibration scales between measurements, limited spatial and temporal data coverage and uncertainties in kinetic parameters used to calculate decomposition rates.

Within the tropics, the region between the level of maximum convective outflow ( $345 \mathrm{~K}$ potential temperature, $\sim 12 \mathrm{~km}$ ) and the cold point tropopause ( $380 \mathrm{~K}$ potential temperature, $\sim 17 \mathrm{~km}$ ) is termed the tropical tropopause layer (TTL) (Law and Sturges, 2007). The TTL acts as a source region for the stratospheric overworld and the extra-tropical lowermost stratosphere. Therefore, mixing ratios of halogenated compounds (including VSLB) in this region are cru- cial for understanding stratospheric ozone depletion in the lower and upper stratosphere.

Although it is not as significant for upper stratospheric ozone depletion, the extra-tropical UTLS is of interest as bidirectional transport influences the chemistry of the upper troposphere (UT) and lower stratosphere (LS). This region is also of significance due to its strong influence on surface climate, climate feedbacks and tropospheric weather regimes (e.g. Gettelman et al., 2011). The chemical, radiative and dynamical properties of this region are coupled. Therefore, changes in chemistry in the UTLS may have consequences for tropospheric chemistry (Anderson et al., 2012) and climate (Riese et al., 2012). Additionally, it is possible that future climate change may impact on VSLB transport into the UTLS through changes in oceanic emissions as ocean temperature and acidity change and also through atmospheric processes such as increased convection and large-scale vertical transport (Dessens et al., 2009) or sea surface temperature, wind speed and marine boundary layer height (Hepach et al., 2014). These factors might increase the quantity of VSLB transported to the UTLS and hence, impact on stratospheric ozone.

The CARIBIC project (Containerised Aircraft for the Regular Investigation of the atmosphere Based on an Instrument Container, www.caribic-atmospheric.com) has, since 2005, made regular deployments of a fully automated containerbased atmospheric laboratory aboard a Lufthansa Airlines Airbus A340-600 (Brenninkmeijer et al., 2007). Flights originate in Frankfurt (Germany) with routes to North America, Asia, Africa and South America. At cruising altitudes (approximately $10-12 \mathrm{~km}$ ), the aircraft typically intersects air masses representative of the free troposphere in the tropics, and both the upper troposphere and lowermost stratosphere (UT/LMS) at mid- to high latitudes. The UT/LMS is of particular interest as this is a complex region of the atmosphere with a limited number of measurements made within it. During each flight, real-time trace-gas and aerosol measurements are made alongside the collection of wholeair samples. A subset of whole-air samples have been analysed for VSLB $\left(\mathrm{CHBr}_{3}, \mathrm{CH}_{2} \mathrm{Br}_{2}, \mathrm{CHBr}_{2} \mathrm{Cl}, \mathrm{CHBrCl}_{2}\right.$ and $\mathrm{CH}_{2} \mathrm{BrCl}$ ) (Sect. 2). Here we provide a description of the analysis of VSLB in CARIBIC and the results obtained.

\section{Methods}

The CARIBIC container instrumentation carries out a number of in situ measurements during each flight (Brenninkmeijer et al., 2007). In addition, whole-air samples are collected for later laboratory analysis. A detailed description of CARIBIC sample collection can be found in Baker et al. (2011a). The whole-air sampler unit consists of a pumping unit and two TRAC (Triggered Retrospective Air Collector) sampling units. Each TRAC contains 14 2.7 L glass sampling flasks with a normal flight consisting of 14 samples taken on 


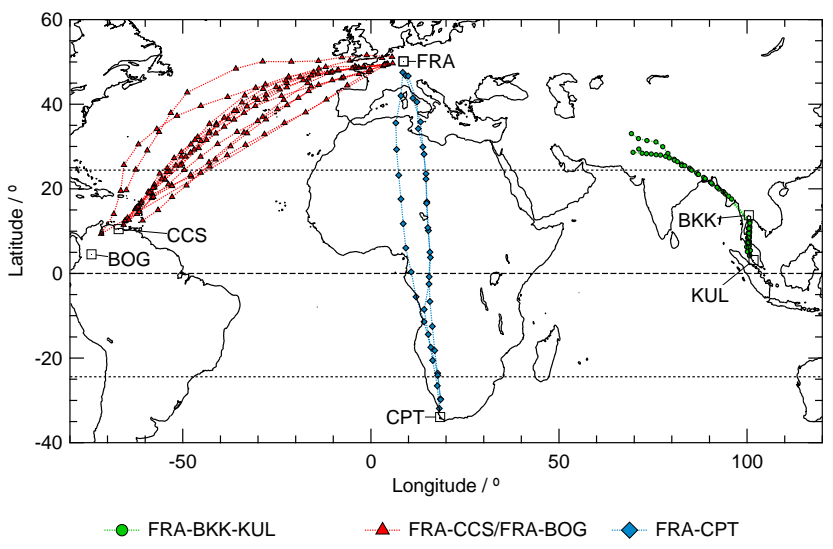

Fig. 1. Collection locations of whole air samples for CARIBIC flight routes FRA-CCS/BOG, FRA-CPT and FRA-BKK-KUL. For the latter, air sample collection north of approximately $30^{\circ} \mathrm{N}$ were not analysed at UEA.

the outbound and 14 on the return flight, making a total of 28 samples per round-trip flight. Samples are collected along the flight route at predetermined, evenly spaced sampling intervals of $\sim 35 \mathrm{~min}$, or $\sim 480 \mathrm{~km}$ between samples. Filling times are on average $45 \mathrm{~s}(30-90 \mathrm{~s})$ corresponding to a spatial coverage of 7-21 km. TRACs are routinely analysed after the flight at different laboratories for non-methane hydrocarbons (Baker et al., 2010), non-halogenated and halogenated greenhouse gases, e.g. $\mathrm{N}_{2} \mathrm{O}, \mathrm{CH}_{4}, \mathrm{SF}_{6}$ and $\mathrm{CO}_{2}$ (Schuck et al., 2010) and a variety of short- and long-lived halocarbons at the University of East Anglia (e.g. Laube et al., 2010, 2012; Baker et al., 2011b; Lai et al., 2011; Oram et al., 2012; Sturges et al., 2012).

Between June 2009 and May 2011 the container was installed on flights between Frankfurt, Germany (FRA) and Caracas, Venezuela (CCS); between Frankfurt and Bogotá, Columbia (BOG), and between Frankfurt and Cape Town, South Africa (CPT). During November and December 2012 and February 2013 the container was installed on flights between Frankfurt and Bangkok, Thailand (BKK) and between Bangkok and Kuala Lumpur, Malaysia (KUL). Figure 1 shows the sampling locations for all Central American flights (FRA-CCS/BOG), South African flights (FRA-CPT) and Southeast Asian flights (FRA-BKK and BKK-KUL). CARIBIC flights are at civil aircraft cruising altitudes and those included in this study were between 6.9 and $12 \mathrm{~km}$ and on average at $\sim 11 \mathrm{~km}(\sim 220 \mathrm{hPa})$.

Routine analysis of whole-air samples for halocarbons is normally carried out by conventional gas chromatography mass spectrometry (GC-MS) in electron ionisation mode (EI-GCMS). However, the analysis of VSLB reported here was performed on a subset of CARIBIC samples using a quadrupole GC-MS running in negative ion chemical ionisation (NICI) mode. NICI has been shown to give much improved response for organic compounds containing bromine and iodine atoms (Worton et al., 2008). The GC-MS (Agilent Technologies GC 6890/MS 5973N) was coupled to a thermal desorption pre-concentrator (UNITY2 ${ }^{\mathrm{TM}}$ and Online Air Server; Markes International Ltd.) as described in Worton et al. (2008). Accurately measured air samples ( $500 \mathrm{~mL}$, flow rate $\sim 40 \mathrm{~mL} \mathrm{~min}^{-1}$ ) were dried with a counterflow nafion drier (Permapure ${ }^{\mathrm{TM}}, 100 \mathrm{~mL} \mathrm{~min}^{-1}$ counterflow of dry nitrogen) prior to pre-concentration on a packed capillary cold trap at $-30^{\circ} \mathrm{C}$ and thermally desorbed at a rate $>60^{\circ} \mathrm{C} \mathrm{s}^{-1}$ to a maximum of $310^{\circ} \mathrm{C}$ for $6 \mathrm{~min}$. Chromatographic separation was achieved using an RTX-502.2 capillary column $\left(105 \mathrm{~m} \times 320 \mu \mathrm{m}\right.$ OD, $1.8 \mu \mathrm{m}$ film, Restek $^{\text {TM }}$ Corporation) using research grade helium $(\geq 99.9995 \%$ purity) as the carrier gas and by temperature-programmed gas chromatography $\left(30^{\circ} \mathrm{C}\right.$ hold $2 \mathrm{~min}, 8^{\circ} \mathrm{Cmin}^{-1}$ to $150^{\circ} \mathrm{C}$ hold $16 \mathrm{~min}, 20^{\circ} \mathrm{Cmin}^{-1}$, to $220^{\circ} \mathrm{C}$ hold $5 \mathrm{~min}$ ). The column effluent was subjected to negative ion chemical ionisation in the presence of methane reagent gas (research grade, $\geq 99.9995 \%$ ) prior to detection by a quadrupole mass selective detector operating in selective ion mode (SIM) and monitoring the $\mathrm{Br}$ ion $(m / z 79,81)$ for brominated compounds. CARIBIC measurements of VSLB are reported as dry-air mole fractions, $\mathrm{pmol} \mathrm{mol}^{-1}$ (dry air), abbreviated here to ppt (parts per trillion).

Analytical uncertainties were calculated on a per-run basis and are the $1 \sigma$ standard deviation of the working standard on the respective measurement day. Estimated limits of detection in parts per trillion (ppt), average compounddependent analytical precisions and the mixing ratios of the working standard at which the measurements where made for the compounds in this study are shown in Table 1. For more details on the working standard see Sect. 2.1.

A number of trace gases are continuously measured through the same inlet line as used for collection of TRAC samples. For each TRAC sample, values for continuously measured trace gases are determined by integration over the sampling period. Ozone $\left(\mathrm{O}_{3}\right)$ measurements used in this study were measured using a custom-made dual-beam UVphotometer, developed and maintained by the Institute for Meteorology and Climate Research, Karlsruhe, Germany with a time resolution of $4 \mathrm{~s}$ and a precision of $0.5 \mathrm{ppb}$ or $0.5 \%$ (whichever is the larger) and a total uncertainty of $1.5 \%$ (Brenninkmeijer et al., 2007; Zahn et al., 2012). Ozone mixing ratios are reported in this study as wet-air mole fractions, $\mathrm{nmol} \mathrm{mol}^{-1}$ (air), abbreviated here to ppb (parts per billion).

Meteorological analyses and backward trajectory calculations are performed along the flight track using the TRAJKS model, of the Royal Netherlands Meteorological Institute (KNMI; Scheele et al. (2007), see also http://www. knmi.nl/samenw/campaign_support/CARIBIC/). The trajectory model uses as input 6 hourly wind fields at $1^{\circ} \times 1^{\circ}$ resolution derived from archived analysis fields from the European Centre for Medium range Weather Forecasting (ECMWF). 5 day back trajectories are calculated along the 
Table 1. Estimated limits of detection (LOD), compound dependant analytical precisions and mixing ratios at which the precision measurement was made for short-lived bromomethane species considered in this study (see Sect. 2.1 for further discussion of the working standard).

\begin{tabular}{lccc}
\hline Species & $\begin{array}{c}\text { Estimated Limit of } \\
\text { Detection (LOD) [ppt] }\end{array}$ & $\begin{array}{c}\text { Mean Analytical } \\
\text { Precision [\%] }\end{array}$ & $\begin{array}{c}\text { Mixing } \\
\text { Ratio [ppt] }\end{array}$ \\
\hline Bromoform & $0.001^{*}$ & 5.3 & $1.57-2.23$ \\
Dibromomethane & $0.001^{*}$ & 5.1 & 1.23 \\
Dibromochloromethane & $0.001^{*}$ & 4.3 & 1.17 \\
Bromodichloromethane & $0.0008^{*}$ & 4.3 & 1.60 \\
Bromochloromethane & 0.005 & 6.1 & 0.29 \\
\hline
\end{tabular}

All LODs given in parts per trillion (ppt) rounded to one significant figure.

* Values from Worton et al. (2008).

flight track at $3 \mathrm{~min}$ intervals. Additionally, at $6 \mathrm{~s}$ time steps, 8 day back trajectories are calculated during the sampling interval of each whole air sample. Additional meteorological parameters, such as potential vorticity $(\mathrm{PV})$, were interpolated along the flight tracks at time intervals of $1 \mathrm{~min}$ by linear interpolation in space and time from the archived ECMWF analyses.

\subsection{Calibration of short-lived halocarbons}

Mixing-ratios of short-lived halocarbons are known to drift when stored for long periods in certain types of metal container (e.g. Laube et al., 2008; Hall et al., 2013; Butler et al., 2007, supplemental). Regular comparisons to known standards are necessary to ensure a consistent dataset. Calibration of the bromocarbons is based on individual compound response factors determined by comparison to a working standard with known mixing ratios. The working standard was an aluminium cylinder containing dry ambient air at high pressure. The mixing ratios of halocarbons in the working standard were determined by repeat comparison to calibrated gas standards supplied by the Global Monitoring Division of NOAA-ESRL in $34 \mathrm{~L}$ electropolished stainless steel canisters (Essex Cryogenics, St. Louis, MO, US). Mixing ratios in these standards are known to be stable over a period of years (e.g. Hall et al., 2013; Butler et al., 2007, supplemental). These comparisons are performed periodically and allow an assessment of any potential changes in the absolute mixing ratio of halocarbons in our working standard over time.

From comparisons with 3 separate NOAA standards: SX3546 (comparison performed in 2008); SX-3570 (2010); and SX-3568 (twice in 2012) we estimate that the mixing ratio of $\mathrm{CHBr}_{3}$ in the working standard has declined by $38 \%$ over the period October 2008-September 2012, whilst that of $\mathrm{CH}_{2} \mathrm{Br}_{2}$ has remained unchanged $(1.23 \pm 0.07 \mathrm{ppt}$, or $5.6 \%, 1 \sigma)$. NOAA calibration data for the 3 mixed bromochloromethanes were only available for the 2010 and 2012 comparisons and our analysis shows that the concentrations of $\mathrm{CH}_{2} \mathrm{BrCl}$ and $\mathrm{CHBr}_{2} \mathrm{Cl}$ in the working standard have remained approximately constant $(0.28 \pm 0.004 \mathrm{ppt}$, or
$1.5 \%$; and $1.18 \pm 0.04 \mathrm{ppt}, 3.4 \%$ respectively) whilst that of $\mathrm{CHBrCl}_{2}$ may have increased by $16 \%$. Calibration factors applied to the CARIBIC data for $\mathrm{CHBr}_{3}$ have been timecorrected using a quadratic fit to the inter-comparison values. A calibration factor was applied to $\mathrm{CH}_{2} \mathrm{Br}_{2}$ based on mean values from 2008-2012 comparisons. Calibration factors for $\mathrm{CHBr}_{2} \mathrm{Cl}, \mathrm{CHBrCl}_{2}$ and $\mathrm{CH}_{2} \mathrm{BrCl}$ are based on the mean values of the 2010 and 2012 comparison. Again, note that the differences in calibration scales for these compounds limit this comparison.

The mixing ratios reported here are therefore based on the latest NOAA-ESRL scales for $\mathrm{CH}_{2} \mathrm{Br}_{2}$ (2004) and $\mathrm{CHBr}_{3}$ (2003), and on a preliminary NOAA scale for $\mathrm{CHBr}_{2} \mathrm{Cl}$, $\mathrm{CHBrCl}_{2}$ and $\mathrm{CH}_{2} \mathrm{BrCl}$ (Brad Hall, personal communication). The accuracy of the absolute mixing ratio in the working standard, based on combined uncertainties associated with the standard comparisons and NOAA's stated uncertainties was $\pm 6.0 \%$ for $\mathrm{CHBr}_{3}, \pm 7.8 \%$ for $\mathrm{CH}_{2} \mathrm{Br}_{2}, \pm 6.7 \%$ for $\mathrm{CHBr}_{2} \mathrm{Cl}, \pm 9.9 \%$ for $\mathrm{CHBrCl}_{2}$ and $\pm 9.0 \%$ for $\mathrm{CH}_{2} \mathrm{BrCl}$.

\section{Results and discussion}

Samples for the following analysis were categorised into tropospheric samples and those with stratospheric influence. Samples with stratospheric influences were defined as having an $\mathrm{O}_{3}$ mixing ratio exceeding the seasonally-dependent ozone threshold value determined by Eq. (1) (Zahn and Brenninkmeijer (2003), confirmed by Thouret et al., 2006). This excludes the influence of stratospheric air on samples and is independent of seasonal variations in the thermal tropopause (see Sect. 3.1.3).

$\mathrm{O}_{3}=97+\sin \left(\frac{2 \pi(\text { Day of Year }-30)}{365}\right)($ in ppb)

\subsection{Central American flights}

\subsubsection{Latitudinal distribution and averages}

Back trajectories from a typical Central American flight are shown in Fig. 2. On this route (FRA-CCS/BOG), the 

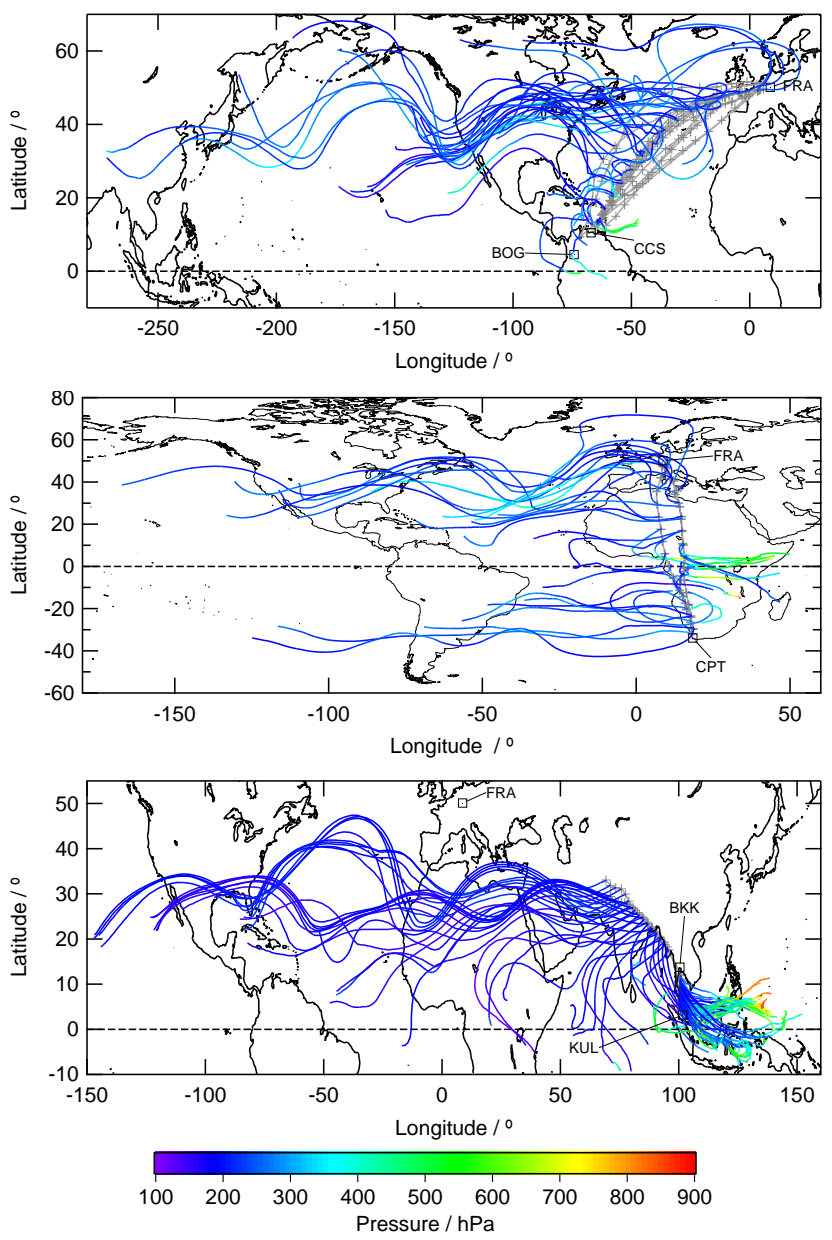

Fig. 2. 5 day back trajectories for the routes sampled in this study (see http://www.knmi.nl/samenw/campaign_support/ CARIBIC/). An example of the air masses sampled along the FRACCS route (top); back trajectories for all samples along FRA-CPT (middle) and back trajectories for all samples along FRA-BKKKUL (bottom).

CARIBIC aircraft samples air mainly originating from the west with some air uplifted from the surface at the northern and southern ends of the flight track.

Figure 3 shows the latitudinal distributions of VSLB during the Central American flights. There is little latitudinal variation over the range covered with larger mixing ratios in only a small number of samples in the tropics compared to higher latitudes. Notably, there are two samples with higher mixing ratios of $\mathrm{CHBr}_{2} \mathrm{Cl}, \mathrm{CHBrCl}_{2}$ and $\mathrm{CH}_{2} \mathrm{BrCl}$ at 10 $20^{\circ} \mathrm{N}$ with no enhancement in $\mathrm{CHBr}_{3}$ and negligible enhancement in $\mathrm{CH}_{2} \mathrm{Br}_{2}$ (see Sect. 4). $\mathrm{CHBr}_{3}$, and to a lesser extent $\mathrm{CHBr}_{2} \mathrm{Cl}$, have lower mean mixing ratios in the region of $20-40^{\circ} \mathrm{N}$ though this is not significant within the uncertainties. $\mathrm{CHBr}_{3}$ and $\mathrm{CHBr}_{2} \mathrm{Cl}$ have the shortest local lifetimes of the five VSLB (24 days and 59 days, respectively, Montzka and Reimann, 2011). This indicates that there has been a higher degree of photochemical processing and mix-
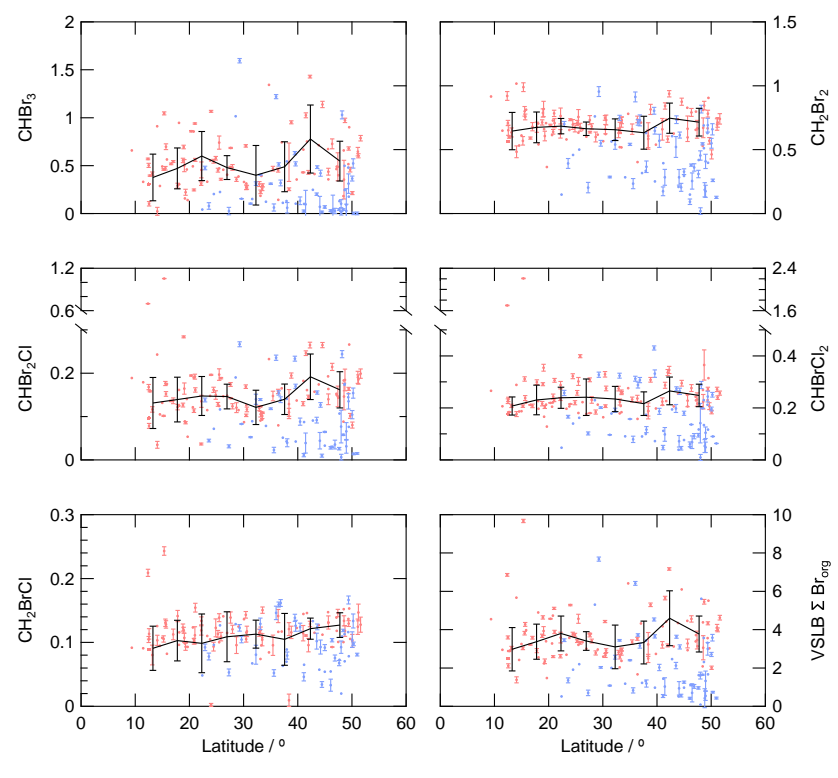

- Tropospheric Stratospheric $\quad 5^{\circ}$ Latitudinal Average

Fig. 3. Northern-hemispheric latitudinal distributions in Central American flights of VSLB and total VSLB-derived bromine (VSLB $\Sigma \mathrm{Br}_{\mathrm{org}}$ ) for tropospheric samples, samples classified as having some stratospheric influence (following the definition in Sect. 3) and $5^{\circ}$ latitudinal means of tropospheric samples above $10 \mathrm{~km}$ altitude with $1 \sigma$ error bars representing variability. Error bars on individual samples represent analytical uncertainties. All VSLB values on the vertical axes are given in ppt.

ing in these air-masses due to longer range transport from high altitudes in these regions as in the example flight in Fig. 2. It is possible that source emission variations could also contribute to lower mixing ratios in this region.

The CARIBIC data can be compared to other recent aircraft studies in the region including CR-AVE, Costa Rica AVE (e.g. Kroon et al., 2008; Aschmann et al., 2009; Hossaini et al., 2010; Ashfold et al., 2012) and HIPPO-1, HIAPER Pole-to-Pole Observations (Wofsy, 2011; Hossaini et al., 2012b, 2013). CR-AVE took place January and February 2006 over the Eastern Pacific and HIPPO-1 took place during January 2009 with some measurements in the region of Central America. HIPPO-1 mixing ratios are on the NOAA scale and are directly comparable to CARIBIC. HIPPO values are based on a regionally relevant subset of all measurements made during the campaign available from the HIPPO data archive (Wofsy et al., 2012). The calibration scale used in CR-AVE has mixing ratios that are $\sim 10 \%$ higher for $\mathrm{CHBr}_{3}$ and $\sim 20 \%$ higher for $\mathrm{CH}_{2} \mathrm{Br}_{2}$ than the NOAA-ESRL scale (Elliot Atlas, personal communication). Additionally, CARIBIC results can be compared to WMO 2010 (Montzka and Reimann, 2011). WMO 2010 values referred to in this study are $10-12 \mathrm{~km}$ upper tropospheric values from Tables 1-7 of WMO 2010. These values are mean values of DC- 8 observations made during the TC4, 
PEM-West A and PEM-West B campaigns (Toon et al., 2010; Hoell et al., 1999, 1997; Schauffler et al., 1999). The minimum and maximum values given in WMO 2010 are based on the smallest mean minus one standard deviation and the largest mean plus one standard deviation respectively, across all campaigns. Again, note that the differences in calibration scales for these compounds limit this comparison.

A summary of the tropical and extra-tropical $10-12.3 \mathrm{~km}$ means and medians for the Central American flights with comparison to literature values is shown in Table 2. Mean values for the tropical region show good agreement with WMO 2010. $\mathrm{CHBrCl}_{2}$ has a larger mean and range in CARIBIC than in WMO 2010.

HIPPO-1 mean mixing ratios agree within the uncertainties given. However, $\mathrm{CH}_{2} \mathrm{Br}_{2}$ is notably higher $(0.88 \mathrm{ppt})$ than in CARIBIC (0.72 ppt) and total VSLB-derived organic bromine (VSLB $\Sigma \mathrm{Br}_{\text {org }}$ ) is similar to CARIBIC (3.2 ppt for HIPPO-1 compared to $3.7 \mathrm{ppt}$ for CARIBIC) without the addition of $\mathrm{CHBrCl}_{2}$ and $\mathrm{CH}_{2} \mathrm{BrCl}$, both of which were unavailable for HIPPO-1. HIPPO-1 samples used in this study were collected further west than the CARIBIC Central American flights which may account for some of the differences in mean mixing ratios. Additionally, his might reflect some seasonality in VSLB, especially $\mathrm{CH}_{2} \mathrm{Br}_{2}$, as HIPPO-1 took place in January whereas CARIBIC Central American flights took place during March-September.

Seasonality has been observed for $\mathrm{CHBr}_{3}$ in the boundary layer (e.g. Carpenter et al., 2005). However, it is uncertain as to whether a seasonal cycle in $\mathrm{CHBr}_{3}$, or other VSLB, would be present in the upper troposphere or the regions sampled in this study. Due to the limited temporal coverage of CARIBIC, seasonal cycles cannot be identified or ruled out. Transport processes and the high degree of variability in source emissions of VSLB could also account for these differences.

CR-AVE mean mixing ratios for $\mathrm{CHBr}_{3}(0.69 \mathrm{ppt})$ and $\mathrm{CH}_{2} \mathrm{Br}_{2}(0.96 \mathrm{ppt})$ are higher than in CARIBIC. However, when differences in calibration scales are taken into account, the CR-AVE means are more similar, i.e. $\sim 0.62 \mathrm{ppt}$ and $\sim 0.77$ ppt for $\mathrm{CHBr}_{3}$ and $\mathrm{CH}_{2} \mathrm{Br}_{2}$ respectively. CRAVE measurements were made further west than CARIBIC and may be more influenced by Pacific and Gulf of Mexico. Significant differences between standards and calibration methodologies for these compounds are known (e.g. Jones et al., 2011) therefore caution should be exercised when drawing conclusions based on these inter-campaign comparisons. This also applies to South African and Southeast Asian routes (see Sects. 3.2 and 3.3).

\subsubsection{Potential temperature}

The tropical tropopause layer (TTL) (between $345 \mathrm{~K}$ and $380 \mathrm{~K}$ potential temperature, approximately $12-17 \mathrm{~km}$ altitude) acts as a source region for the stratospheric overworld and for the extra-tropical lowermost stratosphere (Law and
Sturges, 2007). Figure 4 shows plots of bromocarbons vs. potential temperature $(\Theta)$. Also plotted are $5 \mathrm{~K}$ binned means $\pm 1 \sigma$ vs. $\Theta$. In the tropics, the five VSLB show little change in mean mixing ratio, within the natural variability, with increasing $\Theta$. VSLB $\Sigma \mathrm{Br}_{\text {org }}$ has a maximum mean mixing ratio of $3.74 \mathrm{ppt}$ at $340-345 \mathrm{~K}$. From $340 \mathrm{~K}$ to $355 \mathrm{~K}$ (disregarding the points at lower $\Theta$ as the means are based on only one or two points), the tropical means are higher than in the extra-tropics. This is a possible indication that vertical transport mechanisms in the tropics are a significant factor in supplying VSLB to the stratosphere although this difference is not significant or very small when the natural variability is taken into account. Back trajectory analysis indicates that enhanced mixing ratios in the tropics are due to uplift from the Gulf of Mexico or Eastern Pacific region. The CARIBIC aircraft has a maximum altitude of $\sim 12 \mathrm{~km}$ and reaches potential temperatures of $\sim 360 \mathrm{~K}$, i.e. just at the entrance to the TTL. Therefore, mixing ratios obtained from CARIBIC in the tropics do not directly represent the quantity of VSLB available for transport from within the TTL into the tropical stratosphere. Rather, they represent an upper limit on organic bromine derived from VSLB available for transport into the stratospheric overworld with the proviso that further photochemical processing and physical transport processes will reduce mixing ratios entering the tropical stratosphere.

In the extra-tropics, there is a seasonal variation in the height of the thermal tropopause (e.g. Gettelman et al., 2011). Therefore, binned means $\pm 1 \sigma$ in Fig. 4 are separated, for the extra-tropics, into the two seasonal periods covered by the Central American flights analysed in this study; March, April, May (MAM) and June, July, August and September (JJAS). All five VSLB show an overall decrease in extratropical mean mixing ratio during MAM with increasing $\Theta$; VSLB $\Sigma \mathrm{Br}_{\text {org }}$ decreases from $\sim 3.7 \mathrm{ppt}$ at $320-325 \mathrm{~K}$ to $\sim 1.5 \mathrm{ppt}$ at $340-345 \mathrm{~K}$. No data for MAM are available above $345 \mathrm{~K}$. During JJAS, mean mixing ratios are constant, within the uncertainties, up to $340-345 \mathrm{~K}$ after which there is a decrease to $355-360 \mathrm{~K}$ beyond which there is no data available. VSLB $\Sigma \mathrm{Br}_{\text {org }}$ decreases from $\sim 3.2 \mathrm{ppt}$ to $\sim 0.8 \mathrm{ppt}$ over this range of $\Theta$. This decrease in mixing ratios above $\sim 345 \mathrm{~K}$ corresponds to the extra-tropical tropopause layer (ExTL). There are a number of samples with enhanced mixing ratios in the extra-tropics. However, back trajectories do not indicate a consistent origin for the air in these samples.

\subsubsection{Ozone and height above the tropopause}

$\mathrm{O}_{3}$ is measured in situ on CARIBIC flights and provides an alternative tracer when considering UTLS structure and chemistry. Figure 5 shows plots of the five VSLB and VSLB $\Sigma \mathrm{Br}_{\text {org }}$ against $\mathrm{O}_{3}$ for all FRA-CCS/BOG samples. Data are coloured to show samples with a degree of stratospheric influence. As stated in Sect. 2, tropospheric and stratospherically-influenced samples have been segregated based on a seasonally dependent $\mathrm{O}_{3}$-threshold. This 
Table 2. Summary of tropospheric tropical and extra-tropical 10-12.3 km mid-upper tropospheric means and medians for the bromomethanes and total VSLB-derived organic bromine (VSLB $\Sigma \mathrm{Br}_{\text {org }}$ ) in Central American, South African and Southeast Asian CARIBIC flights (FRACCS/BOG, FRA-CPT, FRA-BKK and BKK-KUL) with comparison to literature values. Tropical is defined as between $24.4378^{\circ} \mathrm{S}$ and $24.4378^{\circ} \mathrm{N}$. Values are means with $\pm 1 \sigma$, medians in curly brackets and minimum/maximum values in parentheses except for WMO 2010 where medians are not given. Values in square brackets are the number of samples included in the average. All values are given in parts per trillion (ppt).

\begin{tabular}{|c|c|c|c|c|c|c|c|c|}
\hline & Campaign & & $\mathrm{CHBr}_{3}$ & $\mathrm{CH}_{2} \mathrm{Br}_{2}$ & $\mathrm{CHBr}_{2} \mathrm{Cl}$ & $\mathrm{CHBrCl}_{2}$ & $\mathrm{CH}_{2} \mathrm{BrCl}$ & $\begin{array}{c}\text { VSLB } \\
\Sigma \mathrm{Br}_{\mathrm{org}}\end{array}$ \\
\hline \multirow[t]{5}{*}{ CARIBIC $^{1}$} & C. America & $\begin{array}{l}\text { Ex. Trop. } \\
{[58]}\end{array}$ & $\begin{array}{c}0.52 \pm 0.27 \\
\{0.45\} \\
(0.14-1.4)\end{array}$ & $\begin{array}{c}0.71 \pm 0.11 \\
\{0.70\} \\
(0.42-0.98)\end{array}$ & $\begin{array}{c}0.15 \pm 0.05 \\
\{0.15\} \\
(0.08-0.27)\end{array}$ & $\begin{array}{c}0.23 \pm 0.05 \\
\{0.22\} \\
(0.15-0.38)\end{array}$ & $\begin{array}{c}0.12 \pm 0.02 \\
\{0.11\} \\
(0.01-0.15)\end{array}$ & $\begin{array}{c}3.6 \pm 1.1 \\
\{3.4\} \\
(1.7-7.2)\end{array}$ \\
\hline & & $\begin{array}{l}\text { Tropical } \\
{[36]}\end{array}$ & $\begin{array}{c}0.52 \pm 0.26 \\
\{0.49\} \\
(0.02-1.1)\end{array}$ & $\begin{array}{c}0.72 \pm 0.14 \\
\{0.71\} \\
(0.38-1.1)\end{array}$ & $\begin{array}{c}0.17 \pm 0.16 \\
\{0.14\} \\
(0.04-1.1)\end{array}$ & $\begin{array}{c}0.27 \pm 0.32 \\
\{0.21\} \\
(0.12-2.1)\end{array}$ & $\begin{array}{c}0.11 \pm 0.03 \\
\{0.10\} \\
(0.0-0.24)\end{array}$ & $\begin{array}{c}3.7 \pm 1.5 \\
\{3.5\} \\
(1.4-9.7)\end{array}$ \\
\hline & S. Africa & $\begin{array}{l}\text { Tropical } \\
{[26]}\end{array}$ & $\begin{array}{c}0.48 \pm 0.54 \\
\{0.35\} \\
(0.03-2.8)\end{array}$ & $\begin{array}{c}0.68 \pm 0.14 \\
\{0.69\} \\
(0.40-0.87)\end{array}$ & $\begin{array}{c}0.14 \pm 0.10 \\
\{0.12\} \\
(0.05-0.55)\end{array}$ & $\begin{array}{c}0.24 \pm 0.10 \\
\{0.22\} \\
(0.10-0.56)\end{array}$ & $\begin{array}{c}0.10 \pm 0.02 \\
\{0.10\} \\
(0.04-0.14)\end{array}$ & $\begin{array}{c}3.4 \pm 2.1 \\
\{2.9\} \\
(1.4-12)\end{array}$ \\
\hline & $\begin{array}{l}\text { S.E. Asia } \\
\text { FRA-BKK }\end{array}$ & $\begin{array}{l}\text { Tropical } \\
>15^{\circ} \mathrm{N} \\
{[18]}\end{array}$ & $\begin{array}{c}0.28 \pm 0.19 \\
\{0.25\} \\
(0.05-0.58)\end{array}$ & $\begin{array}{c}0.76 \pm 0.14 \\
\{0.79\} \\
(0.49-0.95)\end{array}$ & $\begin{array}{c}0.10 \pm 0.04 \\
\{0.10\} \\
(0.04-0.16)\end{array}$ & $\begin{array}{c}0.17 \pm 0.03 \\
\{0.16\} \\
(0.11-0.22)\end{array}$ & $\begin{array}{c}0.10 \pm 0.01 \\
\{0.10\} \\
(0.09-0.12)\end{array}$ & $\begin{array}{c}2.8 \pm 0.93 \\
\{2.8\} \\
(1.6-4.2)\end{array}$ \\
\hline & $\begin{array}{l}\text { S.E. Asia } \\
\text { BKK-KUL }\end{array}$ & $\begin{array}{l}\text { Tropical } \\
0-15^{\circ} \mathrm{N} \\
{[39]}\end{array}$ & $\begin{array}{c}0.56 \pm 0.12 \\
\{0.56\} \\
(0.15-0.81)\end{array}$ & $\begin{array}{c}0.92 \pm 0.08 \\
\{0.93\} \\
(0.74-1.0)\end{array}$ & $\begin{array}{c}0.16 \pm 0.02 \\
\{0.16\} \\
(0.08-0.19)\end{array}$ & $\begin{array}{c}0.21 \pm 0.03 \\
\{0.21\} \\
(0.16-0.31)\end{array}$ & $\begin{array}{c}0.12 \pm 0.01 \\
\{0.12\} \\
(0.09-0.14)\end{array}$ & $\begin{array}{c}4.2 \pm 0.56 \\
\{4.1\} \\
(2.4-5.2)\end{array}$ \\
\hline HIPPO-1 ${ }^{2}$ & C. America & $\begin{array}{l}\text { Tropical } \\
\text { [8] }\end{array}$ & $\begin{array}{c}0.44 \pm 0.07 \\
\{0.44\} \\
(0.34-0.58)\end{array}$ & $\begin{array}{c}0.88 \pm 0.02 \\
\{0.88\} \\
(0.85-0.92)\end{array}$ & $\begin{array}{c}0.13 \pm 0.03 \\
\{0.14\} \\
(0.09-0.15)\end{array}$ & N/A & N/A & $\begin{array}{c}3.2 \pm 0.33 \\
\{3.2\} \\
(2.8-3.9)\end{array}$ \\
\hline \multirow[t]{2}{*}{ HIPPO-4 ${ }^{2}$} & S.E. Asia & $\begin{array}{l}\text { Tropical } \\
>15^{\circ} \mathrm{N} \\
{[10]}\end{array}$ & $\begin{array}{c}0.25 \pm 0.11 \\
\{0.27\} \\
(0.00-0.42)\end{array}$ & $\begin{array}{c}0.69 \pm 0.07 \\
\{0.68\} \\
(0.60-0.83)\end{array}$ & $\begin{array}{c}0.07 \pm 0.02 \\
\{0.08\} \\
(0.04-0.09)\end{array}$ & N/A & N/A & $\begin{array}{c}2.2 \pm 0.42 \\
\quad\{2.3\} \\
(1.26-2.6)\end{array}$ \\
\hline & & $\begin{array}{l}\text { Tropical } \\
0-15^{\circ} \mathrm{N} \\
{[7]}\end{array}$ & $\begin{array}{c}0.80 \pm 0.24 \\
\{0.72\} \\
(0.51-1.2)\end{array}$ & $\begin{array}{c}0.95 \pm 0.09 \\
\{0.95\} \\
(0.83-1.1)\end{array}$ & $\begin{array}{c}0.16 \pm 0.06 \\
\{0.16\} \\
(0.10-0.21)\end{array}$ & N/A & N/A & $\begin{array}{c}4.4 \pm 0.87 \\
\{4.4\} \\
(3.2-5.9)\end{array}$ \\
\hline CR-AVE ${ }^{3}$ & E. Pacific & $\begin{array}{l}\text { Tropical } \\
{[24]}\end{array}$ & $\begin{array}{c}0.69 \pm 0.32 \\
\{0.59\} \\
(0.32-1.5)\end{array}$ & $\begin{array}{c}0.96 \pm 0.11 \\
\{0.96\} \\
(0.80-1.2)\end{array}$ & $\begin{array}{c}0.11 \pm 0.02 \\
\{0.11\} \\
(0.07-0.14)\end{array}$ & N/A & N/A & $\begin{array}{c}4.2 \pm 1.2 \\
\{3.8\} \\
(2.7-7.0)\end{array}$ \\
\hline WMO2010 4 & & Tropical & $\begin{array}{c}0.50 \\
(0.12-1.21)\end{array}$ & $\begin{array}{c}0.86 \\
(0.63-1.21)\end{array}$ & $\begin{array}{c}0.11 \\
(0.01-0.36)\end{array}$ & $\begin{array}{c}0.11 \\
(0.02-0.28)\end{array}$ & $\begin{array}{c}0.09 \\
(0.03-0.16)\end{array}$ & $\begin{array}{c}3.5 \\
(1.7-7.4)\end{array}$ \\
\hline
\end{tabular}

\footnotetext{
1 10-12.3 km mid-upper tropospheric means $\pm 1 \sigma$ and ranges.

2 Wofsy et al. (2012). Averages at 9-12 km altitude. VSLB $\Sigma \mathrm{Br}_{\text {org }}$ does not include $\mathrm{CHBrCl}_{2}$ and $\mathrm{CH}_{2} \mathrm{BrCl}$.

${ }^{3}$ VSLB $\Sigma \mathrm{Br}_{\text {org }}$ derived from $\mathrm{CHBr}_{3}, \mathrm{CH}_{2} \mathrm{Br}_{2}$ and $\mathrm{CHBr}_{2} \mathrm{Cl}$ only.

${ }^{4} 10-12 \mathrm{~km}$. Montzka and Reimann (2011)
}

"chemical tropopause" (CT) lies $\sim 800 \mathrm{~m}$ below the thermal tropopause (Bethan et al., 1996) and approximates to a $\mathrm{CT}$ at $100 \mathrm{ppb}_{3}$ and an upper limit to the mixed ExTL of $\sim 500 \mathrm{ppb} \mathrm{O}_{3}$. Therefore, between the $\mathrm{CT}$ and thermal tropopause there is significant impact from stratospheric air. All five VSLB show a sharp decrease in mixing ratio around 100-200 $\mathrm{ppb} \mathrm{O}_{3}$ corresponding to the transition from the troposphere to the ExTL. Above $200 \mathrm{ppb}_{3}$ mixing ratios do not decrease greatly indicating that this layer is still show- ing some degree of mixing with the troposphere or the influence of quasi-horizontal transport from the tropics. All tropical samples are below the CT due to the restricted altitude range of the aircraft.

An alternate method of viewing the chemical structure within the ExTL is to define a vertical height above the tropopause based on simultaneously measured $\mathrm{O}_{3}$ mixing ratios. $\mathrm{O}_{3}$ mixing ratios can be translated into vertical distance above the thermal tropopause $\left(\mathrm{zO}_{3}\right)$ by comparison to 

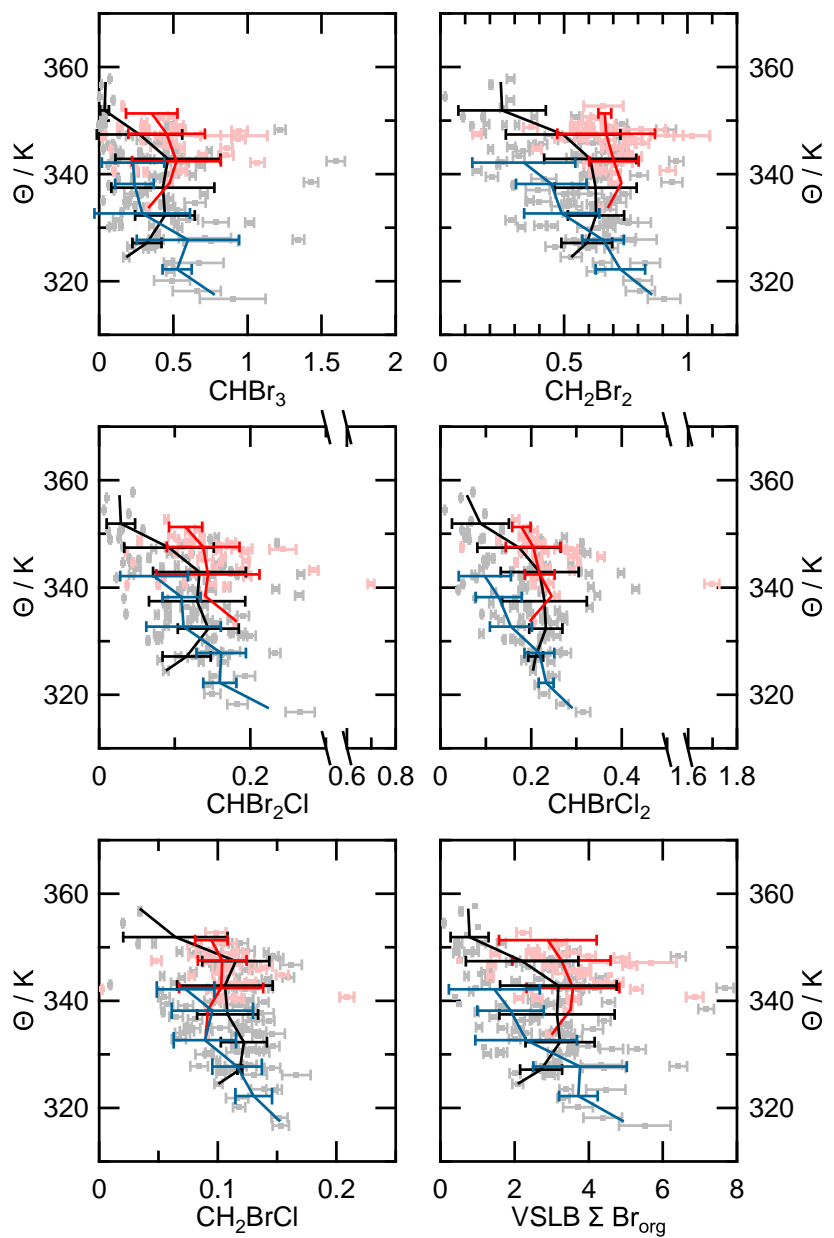

\begin{tabular}{ll} 
- Extratropical samples \\
Tropical samples \\
$-5^{\circ} \Theta$ mean (tropics) \\
$-5^{\circ} \Theta$ mean (extratopics JJAS) \\
\hline & $5^{\circ} \Theta$ mean (extratopics MAM)
\end{tabular}

Fig. 4. Plots of VSLB and total VSLB-derived bromine (VSLB $\Sigma$ $\mathrm{Br}_{\text {org }}$ ) for Central American flights against potential temperature $(\Theta)$ with $5 \mathrm{~K}$ means. $5 \mathrm{~K}$ means with $1 \sigma$ error bars representing variability are separated into extra-tropical from March, April and May (MAM); extra-tropical from June, July, August and September (JJAS) and tropical samples from all months. Where fewer than three data points were available for averaging, error bars have not been added. Error bars on sample data points represent analytical uncertainties. All VSLB values on the horizontal axes are given in ppt.

monthly mean $\mathrm{O}_{3}$ sonde-based profiles (Sprung and Zahn, 2010). Being a relatively long-lived tracer, $\mathrm{O}_{3}$ follows the vertical movement of the tropopause. Therefore, $\mathrm{zO}_{3}$ removes vertical variations in the thermal tropopause from trace gas profiles as shown in Sprung and Zahn (2010).

Figure 6 shows plots for all FRA-CCS/BOG samples of the five VSLB and VSLB $\Sigma \mathrm{Br}_{\text {org }}$ with the height above the thermal tropopause as calculated for CARIBIC following
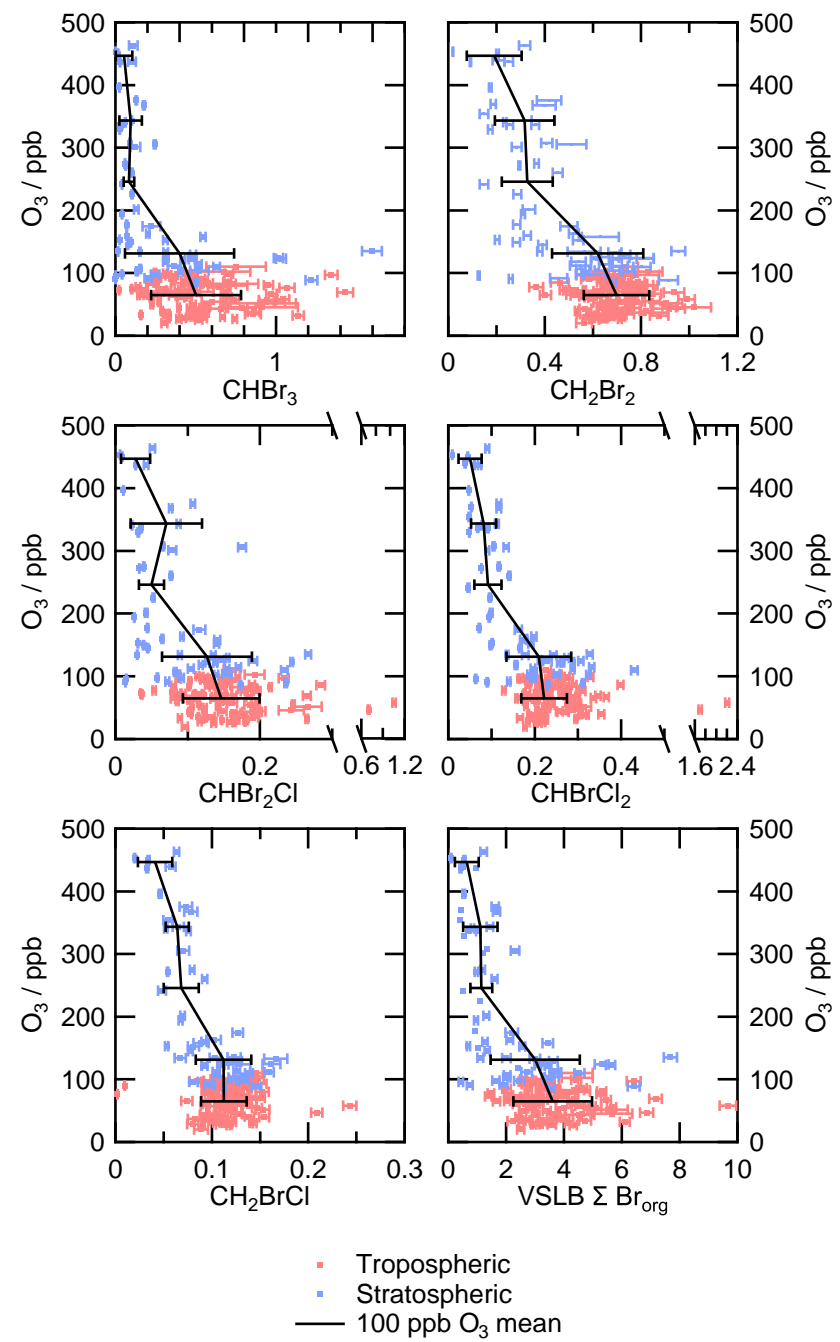

Fig. 5. Plots of VSLB and total VSLB-derived bromine (VSLB $\Sigma$ $\mathrm{Br}_{\text {org }}$ ) for all samples on Central American flights against $\mathrm{O}_{3}$ with $100 \mathrm{ppb}$ binned means $\pm 1 \sigma$ error bars representing variability. Error bars on sample data points represent analytical uncertainties. Data points have been separated by colour into tropospheric samples and those with stratospheric influence (see Sect. 3). All VSLB values on the horizontal axes are given in ppt.

the definition given in Zahn and Brenninkmeijer (2003). Due to the limited cruising altitude range of the aircraft, height above the thermal tropopause is only available for extratropical samples. There is a high degree of variation within $0.5 \mathrm{~km}$ of the tropopause with a lesser degree of variation above $0.5 \mathrm{~km}$. VSLB $\Sigma \mathrm{Br}_{\text {org }}$ decreases from a mean value of $2.3 \mathrm{ppt}$ at $0-0.5 \mathrm{~km}$ above the tropopause to $<0.5 \mathrm{ppt}$ above $3 \mathrm{~km}$ although this number is based on only two samples. This level is at the upper extent of the mixed ExTL layer and puts an upper limit on the quantity of organic-derived bromine entering the lower extra-tropical stratosphere. This, of course, does not give an indication of the quantity of 

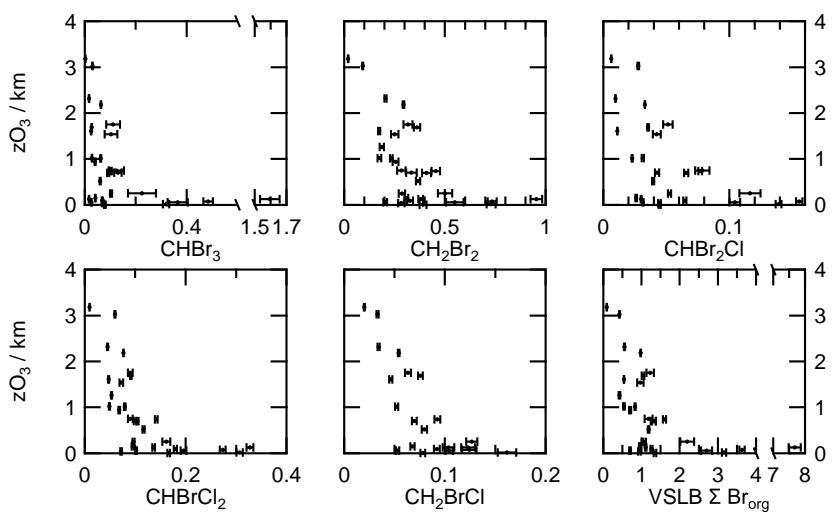

Fig. 6. Plots of VSLB and VSLB-derived total bromine (VSLB $\Sigma \mathrm{Br}_{\text {org }}$ ) for Central American flights with $\mathrm{O}_{3}$-derived height above the thermal tropopause $\left(\mathrm{zO}_{3}\right)$ as defined by $\mathrm{Zahn}$ and Brenninkmeijer (2003). Error bars represent analytical uncertainties. The tropopause is defined as $\mathrm{zO}_{3}=0$ (see Sect. 3.1.3). All VSLB values on the horizontal axes are given in ppt.

product gases (derived from photochemical processing of VSLB) transported into this region.

\subsection{South African flights}

The South African (FRA-CPT) CARIBIC route partly samples air masses with similar origins to the Central American route (Fig. 2 and Sect. 3.1). However, there is also greater latitudinal range over FRA-CPT providing the opportunity to samples air masses from both hemispheres as well as air masses from the African continent and further east.

Analyses for three flights were available for CARIBIC route FRA-CPT (one return flight and one out-bound flight). Latitudinal profiles for these flights are shown in Fig. 7 with $10^{\circ}$ latitudinal means of tropospheric data above $10 \mathrm{~km}$ altitude. When all the data is binned latitudinally, there is some degree of latitudinal gradient in all VSLB with higher values in the northern mid-latitudes declining towards the southern mid-latitudes (see Fig. 7). For example, mean $\mathrm{CHBr}_{3}$ drops from $0.73 \mathrm{ppt}$ to $0.16 \mathrm{ppt}$ and $\mathrm{CH}_{2} \mathrm{Br}_{2}$ from $0.80 \mathrm{ppt}$ to $0.48 \mathrm{ppt}$. These two compounds are the main contributors to VSLB $\Sigma \mathrm{Br}_{\text {org }}$ which drops from $4.5 \mathrm{ppt}$ to $1.8 \mathrm{ppt}$. However, higher mixing ratios in the northern mid-latitudes derive from one FRA-CPT flight leg in February 2011 (the other return flight was in October 2009). Five and eight-day back trajectories shows that air in the northern mid-latitudes originated, on this flight leg, from further south within the Central American tropics rather than from the North American continent and North West Atlantic as in the return flight. Elevated mixing ratios of $\mathrm{CHBr}_{2} \mathrm{Cl}, \mathrm{CHBrCl}_{2}$ and $\mathrm{CH}_{2} \mathrm{BrCl}$ at $25-35^{\circ} \mathrm{S}$ are from the return flight and show a possible influence from the east coast of South America. It is likely that the inter-hemispheric gradient in Fig. 7 is a product of regional influences and the limited temporal range of the data
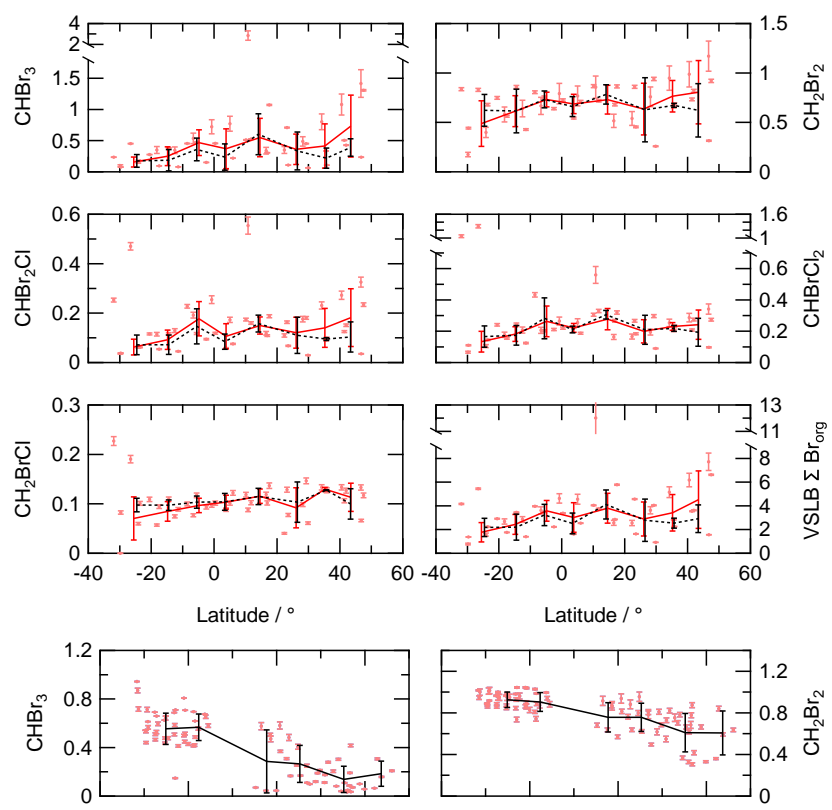

Latitude $/^{\circ}$
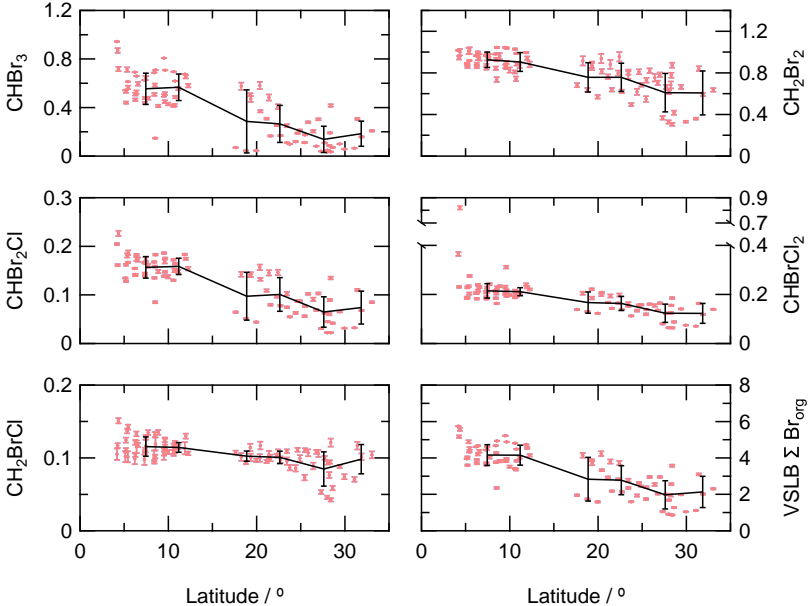

- Samples

$10^{\circ}$ mean (all FRA-CPT samples)
$\ldots . . . .10^{\circ}$ mean (FRA-CPT return flight)

Fig. 7. Latitudinal distributions in South African (top) and Southeast Asia (bottom) flights of VSLB and total VSLB-derived bromine (VSLB $\Sigma \mathrm{Br}_{\text {org }}$ ) with $10^{\circ}$ (South African flights) and $5^{\circ}$ (Southeast Asia) latitudinal means of tropospheric samples above $10 \mathrm{~km}$ altitude with $1 \sigma$ error bars representing variability. Latitudinal averages for South African flights are are shown for all samples and for samples collected on the return flight (see Sect. 3.2). All samples in both routes are tropospheric (following the definition in Sect. 3) with error bars representing analytical uncertainties. All VSLB values on the horizontal axes are given in ppt.

rather than representing a larger-scale gradient. For comparison, over all HIPPO campaigns (HIPPO- 1 and -4 are summarised in Table 2, see also Sects. 3.1.1 and 3.3) there is no comparable inter-hemispheric gradient over a similar latitudinal and altitudinal range.

If the February 2011 flight leg is excluded from the dataset (as in Fig. 7), there is no discernible inter-hemispheric latitudinal gradient. However, there is a possible increase in mixing ratios in all except $\mathrm{CH}_{2} \mathrm{BrCl}$ in the tropics, e.g. $\mathrm{CHBr}_{3}$ is enhanced by up to $\sim 0.4 \mathrm{ppt}$. This increase is small when variability is taken into account with limited sampling. 
Therefore, these results should be taken as suggesting the possibility of a tropical enhancement over Africa rather than being definitive. This is perhaps present in the latitudinal averages across all data but obscured by the apparent latitudinal gradient. The HIPPO campaigns show increased mixing ratios around the equator compared to the extra-tropics (e.g. $\mathrm{CHBr}_{3}$ increases from $\sim 0.2 \mathrm{ppt}$ at $50^{\circ} \mathrm{N}$ to $\sim 0.6 \mathrm{ppt}$ in the tropics); a similar enhancement to the CARIBIC data. It should be noted that the HIPPO campaign was exclusively in the Pacific region. Therefore, it is not directly comparable to the CARIBIC FRA-CPT route except in discussing global patterns. The source of this tropical enhancement is not clearly given by five-day back trajectories (Fig. 2). There is an indication in the back trajectories of strong uplift from the east coast and continental Africa around the equator. One sample in this region shows high levels of $\mathrm{CHBr}_{3}$ (2.85 ppt), $\mathrm{CHBr}_{2} \mathrm{Cl}(0.55 \mathrm{ppt})$ and $\mathrm{CHBrCl}_{2}(0.56 \mathrm{ppt})$. Back trajectory analysis for this sample indicates possible influence from the east coast of Africa in the region of Somalia and/or the Arabian Sea. This samples is from the February 2011 flight leg but is representative, from back trajectory analysis, of air around the equator.

Mean mixing ratios for the tropical mid-troposphere at $10-12.3 \mathrm{~km}$ are presented in Table 2. Values for the extratropical region are not given due to limited data coverage. The values given in Table 2 for $\mathrm{CHBr}_{3}, \mathrm{CHBr}_{2} \mathrm{Cl}, \mathrm{CHBrCl}_{2}$ and $\mathrm{CH}_{2} \mathrm{BrCl}$ agree well, within the uncertainties, with tropical troposphere values for the Central American flights and, therefore, with WMO 2010; $\mathrm{CH}_{2} \mathrm{Br}_{2}$ is $\sim 0.2$ ppt lower. Ranges for $\mathrm{CHBr}_{2} \mathrm{Cl}, \mathrm{CHBrCl}_{2}$ and $\mathrm{CH}_{2} \mathrm{BrCl}$ are similar to WMO 2010 however, the maximum value for $\mathrm{CHBr}_{3}$ in CARIBIC is $\sim 1.6 \mathrm{ppt}$ higher than in WMO 2010 and maximum $\mathrm{CH}_{2} \mathrm{Br}_{2}$ is $\sim 0.4$ ppt lower.

\subsection{Southeast Asia flights}

The tropical West Pacific is considered a potentially important region for transport of VSLB into the stratosphere (e.g. Aschmann et al., 2009). Frequent and intense convection provides an efficient pathway for boundary layer air to be transported to the TTL (e.g. Fueglistaler et al., 2009). Additionally, emissions in the region are poorly sampled, including those of farmed macroalgae species. These could impact on future VSLB emissions due to interest in increasing seaweed aquaculture in the region (Leedham et al., 2013).

Flights between FRA and KUL consist of two legs; FRABKK and BKK-KUL (collectively FRA-BKK-KUL). As bottle samples are only collected at cruising altitude and not during take-off or landing, there is a discontinuity in data coverage in the region of Bangkok. This route intersects air masses, over the FRA-BKK leg, with a range of origins (Fig. 2). The BKK-KUL leg samples a less diverse range of air masses mainly originating over Indonesia and the South China Sea.
A total of three return flights were analysed along the FRA-BKK-KUL route providing good coverage in a region of the tropics that is considered important for VSLB emissions (e.g. Ashfold et al., 2014). Latitudinal profiles for these flights are shown in Fig. 7 with $5^{\circ}$ latitudinal means of tropospheric samples above $10 \mathrm{~km}$ altitude. All five compounds show distinctly higher mixing ratios within $15^{\circ} \mathrm{N}$ of the equator than at higher latitudes with $\mathrm{CHBr}_{3}$ at $\sim 0.6 \mathrm{ppt}$ below $15^{\circ} \mathrm{N}$ compared to $\sim 0.3 \mathrm{ppt}$ at $15-30^{\circ} \mathrm{N}$. This partly reflects the origins of air masses in this region; back trajectories indicate that most air masses on the BKK-KUL leg of the flight have been uplifted from the South China Sea and Western Pacific Ocean. In contrast, the FRA-BKK leg is dominated by long-range, higher altitude transport from over the Atlantic and North American, European, Asian and African continents with a small number of samples near Bangkok uplifted from Indonesia (see Fig. 2). Additionally, as the VSLB are mainly marine sourced, the FRA-BKK leg of the route, which passes over Europe and Asia, might be expected to show relatively lower mixing ratios.

Samples from $0-5^{\circ} \mathrm{N}$ are from below $10 \mathrm{~km}$ altitude and are not included in the latitudinal means however, two of the samples show slightly higher mixing ratios than $5-15^{\circ} \mathrm{N}$ for $\mathrm{CHBr}_{3}, \mathrm{CHBr}_{2} \mathrm{Cl}$ and $\mathrm{CHBrCl}_{2}$. Back trajectories indicate that the air masses originated off the coast of Malaysia in one case and west of Sumatra in the other.

Average values for the tropical troposphere for the FRABKK leg and for the BKK-KUL leg are included in Table 2. Values for the extra-tropical region are not given due to limited data coverage. Means over the FRA-BKK leg for $\mathrm{CHBr}_{2} \mathrm{Cl}, \mathrm{CHBrCl}_{2}$ and $\mathrm{CH}_{2} \mathrm{BrCl}$ agree well with the Central American and South African flights. $\mathrm{CH}_{2} \mathrm{Br}_{2}(0.76 \mathrm{ppt})$ is $0.08-0.11 \mathrm{ppt}$ higher and $\mathrm{CHBr}_{3}(0.28 \mathrm{ppt})$ is $\sim 0.2 \mathrm{ppt}$ lower than Central American and South African flights. This reflects the mix of long and short-scale transport from various regions covered on this leg of the flight and is not representative of emissions and vertical transport from tropical regions.

Mean mixing ratios for $\mathrm{CHBr}_{3}(0.56 \mathrm{ppt}), \mathrm{CHBr}_{2} \mathrm{Cl}$ (0.16 ppt), $\mathrm{CHBrCl}_{2}(0.21 \mathrm{ppt})$ and $\mathrm{CH}_{2} \mathrm{BrCl}(0.12 \mathrm{ppt})$ for the BKK-KUL leg are similar to the South African and Central American CARIBIC routes and agree well within the errors. However, $\mathrm{CH}_{2} \mathrm{Br}_{2}$ (0.92 ppt) is $0.24-0.27 \mathrm{ppt}$ higher than in the South African and Central American flights. This indicates that there is a greater emission of $\mathrm{CH}_{2} \mathrm{Br}_{2}$ in the Southeast Asian Pacific tropics than in either the Western Atlantic or African tropics. Emissions of the other VSLB are more similar. Caveats relating to data limitations, including seasonality, are the same as those discussed in Sect. 3.1.1.

The HIPPO-4, HIAPER Pole-to-Pole Observations (Wofsy, 2011; Hossaini et al., 2013) took place in June and July 2011. HIPPO-4 mixing ratios are on the NOAA scale and are directly comparable to CARIBIC. HIPPO values are based on a subset of all measurements made during the campaign available from the HIPPO data archive (Wofsy et al., 2012). Part of the campaign took place in the 
region of Indonesia and the Philippines, further east than the CARIBIC BKK-KUL leg. Average mixing ratios for this campaign are shown in Table 2. All mixing ratios are on the NOAA scale. $0-15^{\circ} \mathrm{N}$ means for $\mathrm{CH}_{2} \mathrm{Br}_{2}, \mathrm{CHBr}_{2} \mathrm{Cl}$ and VSLB $\Sigma \mathrm{Br}_{\text {org }}$ agree well with BKK-KUL. $\mathrm{CHBr}_{3}$ is higher in HIPPO-4 (0.80 ppt) than in BKK-KUL (0.56 ppt) but this is within the variability.

We suggest that there are two possible reasons for this enhancement in tropical $\mathrm{CH}_{2} \mathrm{Br}_{2}$ between BKK-KUL and Central America or South African flights.

1. The $\mathrm{CHBr}_{3} / \mathrm{CH}_{2} \mathrm{Br}_{2}$ emission ratio might differ between the regions. The enhancement in $\mathrm{CH}_{2} \mathrm{Br}_{2}$ in BKK-KUL is not accompanied by a similar enhancement in $\mathrm{CHBr}_{3}$ and might indicate a lower $\mathrm{CHBr}_{3}$ emission ratio, relative to $\mathrm{CH}_{2} \mathrm{Br}_{2}$, in Southeast Asia. This is not the case in the literature where $\mathrm{CHBr}_{3} / \mathrm{CH}_{2} \mathrm{Br}_{2}$ emission ratios have been reported as broadly consistent over a range of tropical regions (e.g. Brinckmann et al. 2012; Yokouchi et al. 2005; O'Brien et al. 2009). Additionally, $\mathrm{CHBr}_{2} \mathrm{Cl}$ is similar across the tropical regions sampled, indicating that the Southeast Asian emission ratio is lower for $\mathrm{CHBr}_{2} \mathrm{Cl}$. This emission ratio is known to vary regionally, e.g. Brinckmann et al., O'Brien et al. and Yokouchi et al. report varying emission ratios relative to $\mathrm{CH}_{2} \mathrm{Br}_{2}(0.35,0.46$ and 0.7 respectively). Verification of the emission ratios relative to $\mathrm{CH}_{2} \mathrm{Br}_{2}$ in this study is not possible as measurements were too far removed from source to provide a reliable estimate. This hypothesis is based on the assumption that there is no effect, in our data, of seasonality or inter-annual variability.

2. The local lifetime of $\mathrm{CH}_{2} \mathrm{Br}_{2}$ might be longer in Southeast Asia. Montzka and Reimann (2011) give the local lifetime $\left(\tau_{\text {local }}\right)$ of $\mathrm{CH}_{2} \mathrm{Br}_{2}$ as 120 days. This lifetime is dominated by reaction with hydroxyl $(\mathrm{OH})$ radical $\left(\tau_{\mathrm{OH}}=123\right.$ days, $\tau_{\text {photolysis }}=5000$ days $)$. $\mathrm{CHBr}_{3}\left(\tau_{\text {local }}=24\right.$ days $)$ is more influenced by photolysis $\left(\tau_{\mathrm{OH}}=76\right.$ days, $\tau_{\text {photolysis }}=36$ days $)$. Therefore, it could be expected that, within the troposphere, a region of low $\mathrm{OH}$ mixing ratios would lead, after significant photochemical processing, to an enhancement in $\mathrm{CH}_{2} \mathrm{Br}_{2}$ without a significant, concomitant depletion of $\mathrm{CHBr}_{3}$. The mixed halomethanes could be expected to show a similar behaviour, however, the magnitude of this effect would be too small to discern from the analytical uncertainties.

\section{Enhancements in the mixed bromochloromethanes}

We have observed on a few occasions, enhanced mixing ratios of mixed bromochloromethanes $\left(\mathrm{CHBr}_{2} \mathrm{Cl}, \mathrm{CHBrCl}_{2}\right.$ and $\mathrm{CH}_{2} \mathrm{BrCl}$ ) without significant enhancements of $\mathrm{CHBr}_{3}$ or $\mathrm{CH}_{2} \mathrm{Br}_{2}$, e.g. between 10 and $20^{\circ} \mathrm{N}$ in the Central American flights and $30-40^{\circ} \mathrm{S}$ in the South African flights. These samples also show enhancements in chloroform $\left(\mathrm{CHCl}_{3}\right)$, toluene and benzene. This hints at a possible anthropogenic source of trihalomethanes although a biogenic source cannot be ruled out. Disinfection of seawater, freshwater and wastewater is a known anthropogenic source of halomethanes (Quack and Wallace, 2003, and references therein). However, it would be expected that $\mathrm{CHBr}_{3}$ would show an enhancement if this was the case. Due to the altitude of the CARIBIC aircraft and the limitations of following a commercial flight-path, it is not possible to attribute these elevated samples to a distinct source. However, we believe that there is some indication of a source of mixed bromochloromethanes that is independent of $\mathrm{CHBr}_{3}$ and $\mathrm{CH}_{2} \mathrm{Br}_{2}$.

\section{Summary and conclusions}

We report the mixing ratios of five brominated VSLS in samples collected on three routes of the CARIBIC aircraft during 2009-2013. Across the three routes analysed, mean tropical mid-UT mixing ratios were: $\mathrm{CHBr}_{3}, 0.43 \mathrm{ppt}$; $\mathrm{CH}_{2} \mathrm{Br}_{2}, 0.74$ ppt; $\mathrm{CHBr}_{2} \mathrm{Cl}, 0.14$ ppt; $\mathrm{CHBrCl}_{2}, 0.23 \mathrm{ppt}$ and $\mathrm{CH}_{2} \mathrm{BrCl}, 0.11$ ppt. Total bromine across all routes in the tropical mid-UT was $3.4 \pm 1.5$ ppt. These values agree well with values reported in the $2010 \mathrm{WMO} \mathrm{O}_{3}$ assessment (Montzka and Reimann, 2011). Using a 2008 value of $15.2 \pm 0.2 \mathrm{ppt}$ for bromine from Halons and methyl bromide (Montzka and Reimann, 2011), VSLB across all routes accounts for $\sim 19 \%$ of total bromine. As the anthropogenic contribution to atmospheric bromine (mainly halons and methyl bromide) is expected to decrease, coupled with the potential changes in emissions due to climate change (e.g. increases in wind speeds, ocean temperatures etc.), emissions of VSLB are likely to become proportionally more significant in the future.

For each of the tropical regions covered in this study, midUT VSLB $\Sigma \mathrm{Br}_{\text {org }}$ was $3.7 \mathrm{ppt}$ for FRA-CCS/BOG, $3.4 \mathrm{ppt}$ for the FRA-CPT and $4.2 \mathrm{ppt}$ for BKK-KUL. Mixing ratios of $\mathrm{CHBr}_{3}, \mathrm{CHBr}_{2} \mathrm{Cl}, \mathrm{CHBrCl}_{2}$ and $\mathrm{CH}_{2} \mathrm{BrCl}$ were similar between these three routes: $\mathrm{CH}_{2} \mathrm{Br}_{2}$ was relatively enhanced in the Southeast Asian flights and is the main contributor to the $0.5-0.8$ ppt enhancement of total organic bromine compared to Central American and South African tropical mixing ratios.

The percentage contribution of the three minor VSLB $\left(\mathrm{CHBr}_{2} \mathrm{Cl}, \mathrm{CHBrCl}_{2}\right.$ and $\left.\mathrm{CH}_{2} \mathrm{BrCl}\right)$ to total organic bromine derived from the species analysed across all routes in the tropical mid-UT was $18 \pm 4.8 \%$ (range 11-46); $\mathrm{CHBr}_{3}$ and $\mathrm{CH}_{2} \mathrm{Br}_{2}$ together contributed $82 \pm 4.8 \%$ (54-89). Individual contributions were $34 \pm 13 \%$ (4.7-71) for $\mathrm{CHBr}_{3}$, $48 \pm 12 \%$ (14-73) for $\mathrm{CH}_{2} \mathrm{Br}_{2}, 7.8 \pm 2.0 \%$ (2.8-22) for 
$\mathrm{CHBr}_{2} \mathrm{Cl}, 6.9 \pm 3.0 \%$ (3.8-25) for $\mathrm{CHBrCl}_{2}$ and $3.6 \pm 1.3 \%$ (0.0-7.2) for $\mathrm{CH}_{2} \mathrm{BrCl}$.

Considering that these measurements were made at $10-12 \mathrm{~km}$, below the tropical tropopause layer (TTL) ( $12-17 \mathrm{~km})$, further decomposition will occur during ascent in to the stratospheric overworld. This implies that these values constrain the contribution of VSLB to stratospheric bromine to the lower end of 6 (3-8) ppt of stratospheric $\mathrm{BrO}$ required by WMO 2010 to balance the stratospheric bromine budget. Though this study is limited latitudinally, altitudinally and temporally, the large range and number of regular flights means that the CARIBIC passenger aircraft will continue to be an important source of UTLS and free tropospheric data in the future.

Acknowledgements. We would like to thank the CARIBIC team for their efforts in servicing and maintaining the CARIBIC container, Elliot Atlas (University of Miami) for providing data from the HIPPO and AVE campaigns and Stephen Humphrey for his help in analysing the CARIBIC samples. We would also like to thank SHIVA for providing some of the funding for this work. Adam Wisher and Johannes Laube would like to thank NERC for providing funding for their respective studentship (NE/H524506/1) and fellowship (EU-FP7:226224).

Edited by: R. Sander

\section{References}

Anderson, J. G., Wilmouth, D. M., Smith, J. B., and Sayres, D. S.: UV dosage levels in summer: increased risk of ozone loss from convectively injected water vapor., Science, 337, 835-839, doi:10.1126/science.1222978, 2012.

Aschmann, J., Sinnhuber, B.-M., Atlas, E. L., and Schauffler, S. M.: Modeling the transport of very short-lived substances into the tropical upper troposphere and lower stratosphere, Atmos. Chem. Phys., 9, 9237-9247, doi:10.5194/acp-9-9237-2009, 2009.

Ashfold, M. J., Harris, N. R. P., Atlas, E. L., Manning, A. J., and Pyle, J. A.: Transport of short-lived species into the Tropical Tropopause Layer, Atmos. Chem. Phys., 12, 6309-6322, doi:10.5194/acp-12-6309-2012, 2012.

Ashfold, M. J., Ashfold, M. J., Harris, N. R. P., Manning, A. J., Robinson, A. D., Warwick, N. J., and Pyle, J. A.: Estimates of tropical bromoform emissions using an inversion method, Atmos. Chem. Phys., 14, 979-994, doi:10.5194/acp-14-979-2014, 2014.

Baker, A. K., Slemr, F., and Brenninkmeijer, C. A. M.: Analysis of non-methane hydrocarbons in air samples collected aboard the CARIBIC passenger aircraft, Atmos. Meas. Tech., 3, 311-321, doi:10.5194/amt-3-311-2010, 2010.

Baker, A. K., Schuck, T. J., Slemr, F., van Velthoven, P., Zahn, A., and Brenninkmeijer, C. A. M.: Characterization of non-methane hydrocarbons in Asian summer monsoon outflow observed by the CARIBIC aircraft, Atmos. Chem. Phys., 11, 503-518, doi:10.5194/acp-11-503-2011, 2011a.

Baker, A. K., Rauthe-Schöch, A., Schuck, T. J., Brenninkmeijer, C. A. M., van Velthoven, P. F. J., Wisher, A., and
Oram, D. E.: Investigation of chlorine radical chemistry in the Eyjafjallajökull volcanic plume using observed depletions in non-methane hydrocarbons, Geophys. Res. Lett., 38, 1-6, doi:10.1029/2011GL047571, 2011 b.

Bethan, S., Vaughan, G., and Reid, S. J.: A comparison of ozone and thermal tropopause heights and the impact of tropopause definition on quantifying the ozone content of the troposphere, Q. J. Roy. Meteor. Soc., 122, 929-944, 1996.

Brenninkmeijer, C. A. M., Crutzen, P., Boumard, F., Dauer, T., Dix, B., Ebinghaus, R., Filippi, D., Fischer, H., Franke, H., Frieß, U., Heintzenberg, J., Helleis, F., Hermann, M., Kock, H. H., Koeppel, C., Lelieveld, J., Leuenberger, M., Martinsson, B. G., Miemczyk, S., Moret, H. P., Nguyen, H. N., Nyfeler, P., Oram, D., O’Sullivan, D., Penkett, S., Platt, U., Pupek, M., Ramonet, M., Randa, B., Reichelt, M., Rhee, T. S., Rohwer, J., Rosenfeld, K., Scharffe, D., Schlager, H., Schumann, U., Slemr, F., Sprung, D., Stock, P., Thaler, R., Valentino, F., van Velthoven, P., Waibel, A., Wandel, A., Waschitschek, K., Wiedensohler, A., Xueref-Remy, I., Zahn, A., Zech, U., and Ziereis, H.: Civil Aircraft for the regular investigation of the atmosphere based on an instrumented container: The new CARIBIC system, Atmos. Chem. Phys., 7, 4953-4976, doi:10.5194/acp-7-4953-2007, 2007.

Brinckmann, S., Engel, A., Bönisch, H., Quack, B., and Atlas, E.: Short-lived brominated hydrocarbons - observations in the source regions and the tropical tropopause layer, Atmos. Chem. Phys., 12, 1213-1228, doi:10.5194/acp-12-1213-2012, 2012.

Butler, J. H., King, D. B., Lobert, J. M., Montzka, S. A., YvonLewis, S. A., Hall, B. D., Warwick, N. J., Mondeel, D. J., Aydin, M., and Elkins, J. W.: Oceanic distributions and emissions of short-lived halocarbons, Global Biogeochem. Cy., 21, 1-11, doi:10.1029/2006GB002732, 2007.

Carpenter, L. J., Wevill, D. J., O’Doherty, S., Spain, G. and Simmonds, P. G.: Atmospheric bromoform at Mace Head, Ireland: seasonality and evidence for a peatland source, Atmos. Chem. Phys., 5, 2927-2934, doi:10.5194/acp-5-2927-2005, 2005.

Carpenter, L. J., Jones, C. E., Dunk, R. M., Hornsby, K. E., and Woeltjen, J.: Air-sea fluxes of biogenic bromine from the tropical and North Atlantic Ocean, Atmos. Chem. Phys., 9, 1805-1816, doi:10.5194/acp-9-1805-2009, 2009.

Dessens, O., Zeng, G., Warwick, N., and Pyle, J.: Short-lived bromine compounds in the lower stratosphere; impact of climate change on ozone, Atmos. Sci. Lett., 10, 201-206, doi:10.1002/asl.236, 2009.

Fueglistaler, S., Dessler, A. E., Dunkerton, T. J., Folkins, I., Fu, Q. and Mote, P. W.: Tropical tropopause layer, Rev. Geophys., 47, RG1004, doi:10.1029/2008RG000267, 2009.

Gettelman, A., Hoor, P., Pan, L. L., Randel, W. J., Hegglin, M. I., and Birner, T.: The extratropical upper troposphere and lower stratosphere, Rev. Geophys., 49, 1-31, doi:10.1029/2011RG000355, 2011.

Hall, B. D., Engel, A., Mühle, J., Elkins, J. W., Artuso, F., Atlas, E., Aydin, M., Blake, D., Brunke, E.-G., Chiavarini, S., Fraser, P. J., Happell, J., Krummel, P. B., Levin, I., Loewenstein, M., Maione, M., Montzka, S. A., O'Doherty, S., Reimann, S., Rhoderick, G., Saltzman, E. S., Scheel, H. E., Steele, L. P., Vollmer, M. K., Weiss, R. F., Worthy, D., and Yokouchi, Y.: Results from the International Halocarbons in Air Comparison 
Experiment (IHALACE), Atmos. Meas. Tech. Discuss., 6, 80218069, doi:10.5194/amtd-6-8021-2013, 2013.

Hepach, H., Quack, B., Ziska, F., Fuhlbrügge, S., Atlas, E. L., Krüger, K., Peeken, I., and Wallace, D. W. R.: Drivers of diel and regional variations of halocarbon emissions from the tropical North East Atlantic, Atmos. Chem. Phys., 14, 1255-1275, doi:10.5194/acp-14-1255-2014, 2014.

Hoell, J. M., Davis, D. D., Liu, S. C., Newell, R. E., Akimoto, H., McNeal, R. J. and Bendura, R. J.: The Pacific Exploratory Mission-West Phase B: February-March, 1994, J. Geophys. Res., 102, 28223-28239, doi:10.1029/97JD02581, 1997.

Hoell, J. M., Davis, D. D., Jacob, D. J., Rodgers, M. O., Newell, R. E., Fuelberg, H. E., Mcneal, R. J., Raper, J. L. and Bendura, R. J.: Pacific Exploratory Mission in the tropical Pacific :PEM-Tropics A, August-September 1996, J. Geophys. Res., 104, 5567-5583, doi:10.1029/1998JD100074, 1999.

Hossaini, R., Chipperfield, M. P., Monge-Sanz, B. M., Richards, N. A. D., Atlas, E., and Blake, D. R.: Bromoform and dibromomethane in the tropics: a 3-D model study of chemistry and transport, Atmos. Chem. Phys., 10, 719-735, doi:10.5194/acp-10-719-2010, 2010.

Hossaini, R., Chipperfield, M. P., Dhomse, S., Ordóñez, C., SaizLopez. A., Abraham, N. L., Archibald, A. T., Braesicke, P., Telford, P., Warwick, N., and Pyle, J. A.: Modelling future changes to the stratospheric source gas injection of biogenic bromocarbons, Geophys. Res. Lett., 39, L20813, doi:10.1029/2012GL053401, 2012a.

Hossaini, R., Chipperfield, M. P., Feng, W., Breider, T. J., Atlas, E., Montzka, S. A., Miller, B. R., Moore, F., and Elkins, J.: The contribution of natural and anthropogenic very short-lived species to stratospheric bromine, Atmos. Chem. Phys., 12, 371-380, doi:10.5194/acp-12-371-2012, 2012b.

Hossaini, R., Mantle, H., Chipperfield, M. P., Montzka, S. A., Hamer, P., Ziska, F., Quack, B., Krüger, K., Tegtmeier, S., Atlas, E., Sala, S., Engel, A., Bönisch, H., Keber, T., Oram, D., Mills, G., Ordóñez, C., Saiz-Lopez, A., Warwick, N., Liang, Q., Feng, W., Moore, F., Miller, B. R., Marécal, V., Richards, N. A. D., Dorf, M., and Pfeilsticker, K.: Evaluating global emission inventories of biogenic bromocarbons, Atmos. Chem. Phys., 13, 11819-11838, doi:10.5194/acp-13-11819-2013, 2013.

Kroon, M., Petropavlovskikh, I., Shetter, R., Hall, S., Ullmann, K., Veefkind, J. P., McPeters, R. D., Browell, E. V., and Levelt, P. F.: OMI total ozone column validation with AuraAVE CAFS observations, J. Geophys. Res., 113, D15S13, doi:10.1029/2007JD008795, 2008.

Lai, S. C., Baker, A. K., Schuck, T. J., Slemr, F., Brenninkmeijer, C. A. M., van Velthoven, P., Oram, D. E., Zahn, A., and Ziereis, H.: Characterization and source regions of 51 high-CO events observed during Civil Aircraft for the Regular Investigation of the Atmosphere Based on an Instrument Container (CARIBIC) flights between south China and the Philippines, 2005-2008, J. Geophys. Res., 116, 2005-2008, doi:10.1029/2011JD016375, 2011.

Laube, J. C., Engel, A., Bönisch, H., Möbius, T., Worton, D. R., Sturges, W. T., Grunow, K., and Schmidt, U.: Contribution of very short-lived organic substances to stratospheric chlorine and bromine in the tropics - a case study, Atmos. Chem. Phys., 8, 7325-7334, doi:10.5194/acp-8-7325-2008, 2008.
Laube, J. C., Martinerie, P., Witrant, E., Blunier, T., Schwander, J., Brenninkmeijer, C. A. M., Schuck, T. J., Bolder, M., Röckmann, T., van der Veen, C., Bönisch, H., Engel, A., Mills, G. P., Newland, M. J., Oram, D. E., Reeves, C. E., and Sturges, W. T.: Accelerating growth of HFC-227ea (1,1,1,2,3,3,3-heptafluoropropane) in the atmosphere, Atmos. Chem. Phys., 10, 5903-5910, doi:10.5194/acp-10-5903-2010, 2010.

Laube, J. C., Hogan, C., Newland, M. J., Mani, F. S., Fraser, P. J., Brenninkmeijer, C. A. M., Martinerie, P., Oram, D. E., Röckmann, T., Schwander, J., Witrant, E., Mills, G. P., Reeves, C. E., and Sturges, W. T.: Distributions, long term trends and emissions of four perfluorocarbons in remote parts of the atmosphere and firn air, Atmos. Chem. Phys., 12, 4081-4090, doi:10.5194/acp12-4081-2012, 2012.

Law, K. S. and Sturges, W. T.: Halogenated Very Short-Lived Substances, in: Sci. Assess. Ozone Deplet. 2006, Glob. Ozone Res. Monit. Proj. Rep. No. 50, February, chap. 2, 2.1-2.57, World Meteorological Organization (WMO), Geneva, Switzerland, http://www.unep.ch/Ozone/Assessment_Panels/SAP/Scientific_ Assessment_2006/04-Chapter_2.pdf, 2007.

Leedham, E. C., Hughes, C., Keng, F. S. L., Phang, S.-M., Malin, G., and Sturges, W. T.: Emission of atmospherically significant halocarbons by naturally occurring and farmed tropical macroalgae, Biogeosciences, 10, 3615-3633, doi:10.5194/bg10-3615-2013, 2013.

Montzka, S. A. and Reimann, S.: Chapter 1: Ozone-Depleting Substances (ODSs) and Related Chemicals, in: WMO (World Meteorol. Organ. Sci. Assess. Ozone Deplet. 2010 Glob. Res. Monit. Proj. - Rep. No. 52, edited by: Ennis, C. E., 52, chap. 1, World Meteorological Organization, Geneva, Switzerland, 2011.

O’Brien, L. M., Harris, N. R. P., Robinson, A. D., Gostlow, B., Warwick, N., Yang, X., and Pyle, J. A.: Bromocarbons in the tropical marine boundary layer at the Cape Verde Observatory - measurements and modelling, Atmos. Chem. Phys., 9, 9083-9099, doi:10.5194/acp-9-9083-2009, 2009.

Oram, D. E., Mani, F. S., Laube, J. C., Newland, M. J., Reeves, C. E., Sturges, W. T., Penkett, S. A., Brenninkmeijer, C. A. M., Röckmann, T., and Fraser, P. J.: Long-term tropospheric trend of octafluorocyclobutane $\left(\mathrm{c}-\mathrm{C}_{4} \mathrm{~F}_{8}\right.$ or PFC318), Atmos. Chem. Phys., 12, 261-269, doi:10.5194/acp-12261-2012, 2012.

Quack, B. and Wallace, D.: Air-sea flux of bromoform: Controls, rates, and implications, Global Biogeochem. Cy., 17, 1023, doi:10.1029/2002GB001890, 2003.

Riese, M., Ploeger, F., Rap, A., Vogel, B., Konopka, P., Dameris, M., Forster, P., and Foster, P.: Impact of uncertainties in atmospheric mixing on simulated UTLS composition and related radiative effects, J. Geophys. Res., 117, D16305, doi:10.1029/2012JD017751, 2012.

Schauffler, S. M. Atlas, E. L., Blake, D. R., Flocke, F., Lueb, R. A., Lee-Taylor, J. M., Stroud, V., and Travnicek, W.: Distributions of brominated organic compounds in the troposphere and lower stratosphere, J. Geophys. Res., 104, 21513-21535, doi:10.1029/1999JD900197, 1999.

Scheele, M. P., Siegmund, P. C., and Van Velthoven, P. F. J.: Sensitivity of trajectories to data resolution and its dependence on the starting point: in or outside a tropopause fold, Meteorol. Appl., 3, 267-273, doi:10.1002/met.5060030308, 2007. 
Schuck, T. J., Brenninkmeijer, C. A. M., Baker, A. K., Slemr, F., von Velthoven, P. F. J., and Zahn, A.: Greenhouse gas relationships in the Indian summer monsoon plume measured by the CARIBIC passenger aircraft, Atmos. Chem. Phys., 10, 39653984, doi:10.5194/acp-10-3965-2010, 2010.

Sinnhuber, B.-M., Sheode, N., Sinnhuber, M., Chipperfield, M. P., and Feng, W.: The contribution of anthropogenic bromine emissions to past stratospheric ozone trends: a modelling study, Atmos. Chem. Phys., 9, 2863-2871, doi:10.5194/acp-9-2863-2009, 2009.

Sprung, D. and Zahn, A.: Acetone in the upper troposphere/lowermost stratosphere measured by the CARIBIC passenger aircraft: distribution, seasonal cycle, and variability, J. Geophys. Res., 115, 1-12, doi:10.1029/2009JD012099, 2010.

Sturges, W. T., Oram, D. E., Laube, J. C., Reeves, C. E., Newland, M. J., Hogan, C., Martinerie, P., Witrant, E., Brenninkmeijer, C. A. M., Schuck, T. J., and Fraser, P. J.: Emissions halted of the potent greenhouse gas $\mathrm{SF}_{5} \mathrm{CF}_{3}$, Atmos. Chem. Phys., 12, 3653-3658, doi:10.5194/acp-12-3653-2012, 2012.

Thouret, V., Cammas, J.-P., Sauvage, B., Athier, G., Zbinden, R., Nédélec, P., Simon, P., and Karcher, F.: Tropopause referenced ozone climatology and inter-annual variability (1994-2003) from the MOZAIC programme, Atmos. Chem. Phys., 6, 1033-1051, doi:10.5194/acp-6-1033-2006, 2006.

Toon, O. B., Starr, D. O., Jensen, E. J., Newman, P. A., Platnick, S., Schoeberl, M. R., Wennberg, P. O., Wofsy, S. C., Kurylo, M. J., Maring, H., Jucks, K. W., Craig, M. S., Vasques, M. F., Pfister, L., Rosenlof, K. H., Selkirk, H. B., Colarco, P. R., Kawa, S. R., Mace, G. G., Minnis, P. and Pickering, K. E.: Planning, implementation, and first results of the Tropical Composition, Cloud and Climate Coupling Experiment (TC4), J. Geophys. Res., 115, D00J04, doi:10.1029/2009JD013073, 2010.

Wofsy, S. C.: HIAPER Pole-to-Pole Observations (HIPPO): finegrained, global-scale measurements of climatically important atmospheric gases and aerosols., Philos. Trans. R. Soc. A, 369, 2073-86, doi:10.1098/rsta.2010.0313, 2011.
Wofsy, S. C., Daube, B. C., Jimenez, R., Kort, E., Pittman, J. V., Park, S., Commane, R., Xiang, B., Santoni, G., Jacob, D., Fisher, J., Pickett-Heaps, C., Wang, H., Wecht, K., Wang, Q.Q., Stephens, B. B., Shertz, S., Watt, A., Romashkin, P., Campos, T., Haggerty, J., Cooper, W. A., Rogers, D., Beaton, S., Hendershot, R., Elkins, J. W., Fahey, D. W., Gao, R. S., Moore, F., Montzka, S. A., Schwarz, J. P., Perring, A. E., Hurst, D., Miller, B. R., Sweeney, C., Oltmans, S., Nance, D., Hintsa, E., Dutton, G., Watts, L. A., Spackman, J. R., Rosenlof, K. H., Ray, E. A., Hall, B., Zondlo, M. A., Diao, M., Keeling, R., Bent, J., Atlas, E. L., Lueb, R., and Mahoney, M. J.: HIPPO Combined Discrete Flask and GC Sample GHG, Halo-, Hydrocarbon Data (R_20121129), doi:10.3334/CDIAC/hippo_012 (Release 20121129) [File names: HIPPO_discrete_continuous_merge_20121129.tbl], 2012.

Worton, D. R., Mills, G. P., Oram, D. E., and Sturges, W. T.: Gas chromatography negative ion chemical ionization mass spectrometry: application to the detection of alkyl nitrates and halocarbons in the atmosphere., J. Chromatogr. A, 1201, 112-9, doi:10.1016/j.chroma.2008.06.019, 2008.

Yokouchi, Y., Hasebe, F., Fujiwara, M., Takashima, H., Shiotani, M., Nishi, N., Kanaya, Y., Hashimoto, S., Fraser, P., Toom-Sauntry, D., Mukai, H., and Nojiri, Y.: Correlations and emission ratios among bromoform, dibromochloromethane, and dibromomethane in the atmosphere, J. Geophys. Res., 110, D23309, doi:10.1029/2005JD006303, 2005.

Zahn, A. and Brenninkmeijer, C. A. M.: New Directions: a chemical tropopause defined, Atmos. Environ., 37, 439-440, doi:10.1016/S1352-2310(02)00901-9, 2003.

Zahn, A., Weppner, J., Widmann, H., Schlote-Holubek, K., Burger, B., Kühner, T., and Franke, H.: A fast and precise chemiluminescence ozone detector for eddy flux and airborne application, Atmos. Meas. Tech., 5, 363-375, doi:10.5194/amt-5-3632012, 2012. 